Article

\title{
Joint Interpretation of Geophysical Results and Geological Observations for Detecting Buried Active Faults: The Case of the "Il Lago" Plain (Pettoranello del Molise, Italy)
}

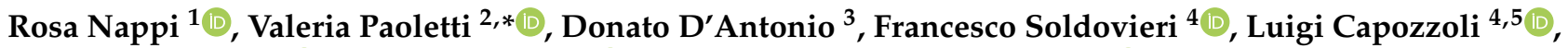 \\ Giovanni Ludeno ${ }^{4}\left(\mathbb{D}\right.$, Sabina Porfido ${ }^{1,6}{ }^{(D)}$ and Alessandro Maria Michetti ${ }^{7}$
}

1 Istituto Nazionale di Geofisica e Vulcanologia, Sezione di Napoli Osservatorio Vesuviano, Via Diocleziano 328, 80124 Naples, Italy; rosa.nappi@ingv.it (R.N.); sabina.porfido@isa.cnr.it (S.P.)

2 Department of Earth, Environment and Resources Science, University Federico II, Complesso di Monte S. Angelo, Via Cintia, Edifice L, 80126 Naples, Italy

3 Geophysical consultant, Vicolo III San Nicola, 2, 86013 Gambatesa, Italy; info@tellura.it

4 Institute for Electromagnetic Sensing of the Environment, National Research Council, Via Diocleziano 328 , 80124 Naples, Italy; soldovieri.f@irea.cnr.it (F.S.); luigi.capozzoli@imaa.cnr.it (L.C.); ludeno.g@irea.cnr.it (G.L.)

5 Institute of Methodologies for Environmental Analysis, National Research Council, C.da S. Loja-Zona Industriale, 85050 Tito Scalo, Italy

6 Consiglio Nazionale delle Ricerche-Isa, Via Roma 64, 83100 Avellino, Italy

7 Dipartimento di Scienza e Alta Tecnologia, Università degli Studi dell'Insubria, Via Valleggio, 11, 22100 Como, Italy; alessandro.michetti@uninsubria.it

* Correspondence: paoletti@unina.it; Tel.: +39-0812538149

Citation: Nappi, R.; Paoletti, V.; D'Antonio, D.; Soldovieri, F.;

Capozzoli, L.; Ludeno, G.; Porfido, S.; Michetti, A.M. Joint Interpretation of Geophysical Results and Geological Observations for Detecting Buried Active Faults: The Case of the "Il Lago" Plain (Pettoranello del Molise, Italy). Remote Sens. 2021, 13, 1555. https://doi.org/10.3390/rs13081555

Received: 24 February 2021

Accepted: 14 April 2021

Published: 17 April 2021

Publisher's Note: MDPI stays neutral with regard to jurisdictional claims in published maps and institutional affiliations.

Copyright: (c) 2021 by the authors. Licensee MDPI, Basel, Switzerland. This article is an open access article distributed under the terms and conditions of the Creative Commons Attribution (CC BY) license (https:// creativecommons.org/licenses/by/ $4.0 /)$.
Abstract: We report a geophysical study across an active normal fault in the Southern Apennines. The surveyed area is the "Il Lago" Plain (Pettoranello del Molise), at the foot of Mt. Patalecchia (Molise Apennines, Southern Italy), a small tectonic basin filled by Holocene deposits located at the NW termination of the major Quaternary Bojano basin structure. This basin, on the NE flank of the Matese Massif, was the epicentral area of the very strong 26 July, 1805, Sant'Anna earthquake (I0 = X MCS, $\mathrm{Mw}=6.7$ ). The "Il Lago" Plain is bordered by a portion of the right-stepping normal fault system bounding the whole Bojano Quaternary basin ( $28 \mathrm{~km}$ long). The seismic source responsible for the 1805 earthquake is regarded as one of the most hazardous structures of the Apennines; however, the position of its NW boundary of this seismic source is debated. Geological, geomorphological and macroseismic data show that some coseismic surface faulting also occurred in correspondence with the border fault of the "Il Lago" Plain. The study of the "Il Lago" Plain subsurface might help to constrain the NW segment boundary of the 1805 seismogenic source, suggesting that it is possibly a capable fault, source for moderate $(\mathrm{Mw}<5.5)$ to strong earthquakes ( $\mathrm{Mw} \geq 5.5)$. Therefore, we constrained the geometry of the fault beneath the plain using low-frequency Ground Penetrating Radar (GPR) data supported by seismic tomography. Seismic tomography yielded preliminary information on the subsurface structures and the dielectric permittivity of the subsoil. A set of GPR parallel profiles allowed a quick and high-resolution characterization of the lateral extension of the fault, and of its geometry at depth. The result of our study demonstrates the optimal potential of combined seismic and deep GPR surveys for investigating the geometry of buried active normal faults. Moreover, our study could be used for identifying suitable sites for paleoseismic analyses, where record of earthquake surface faulting might be preserved in Holocene lacustrine sedimentary deposits. The present case demonstrates the possibility to detect with high accuracy the complexity of a fault-zone within a basin, inferred by GPR data, not only in its shallower part, but also down to about $100 \mathrm{~m}$ depth.

Keywords: active faults; Ground Penetrating Radar; 1805 Sant'Anna earthquake; Bojano basin; Il Lago Plain (Molise Apennines, Italy) 


\section{Introduction}

Only limited portions of active brittle fault zones are exposed at the surface, due to the combination of limited tectonic rock exhumation and erosion [1]. In particular, active normal faults typically trigger rapid feedback response of surface processes, such as gravitational instability and erosional dismantling of the uplifted footwall blocks, coupled with enhanced sedimentation in the downthrown hanging wall counterpart (e.g., [1-4]). In the Southern Apennines of Italy, tectonically active extensional structures are characterized by low strain-rates and a tectonic architecture (e.g., [5-7] and reference therein) inherited from previous phases of shortening. Here, the identification and characterization of active faults is not always straightforward. Moreover, the distributed deformation on segmented normal fault-systems and the presence of thick clastic covers may mask important details of the active fault structure, making it difficult to correctly interpret the signature of recent faulting (e.g., [5,8,9]). For these reasons, a geological approach based on traditional geomorphic and structural observations should be assisted by geophysical investigation, which can provide effective insight for the characterization of active faults segments. Geophysical active and passive methods can indeed yield important information on the subsoil characteristics and/or rupture planes geometry (e.g., [10-14]).

In this paper, we present the results of a relevant case-history, with the recent geophysical survey performed by seismic refraction tomography and Ground Penetrating Radar (GPR) to characterize the active buried fault bordering the western edge of the "Il Lago" Plain (Pettoranello del Molise), at the foot of Mt. Patalecchia (Molise Apennines, Southern Italy; Figure 1). The survey area, "Il Lago" is a small endoreic basin that closes the structure of the NW-SE Quaternary Bojano basin towards NW. The plain is bordered by a portion of the $28 \mathrm{~km}$ long, right-stepping normal fault system bounding the whole Bojano Quaternary basin. This fault system is considered one of the most seismically hazardous structure of the Apennines $[15,16]$. The whole region is one of the most seismically active areas of the Southern Apennines repeatedly hit during the last centuries by destructive earthquakes: the 5 December, 1456 earthquake ( $I=X I$ MCS; $\mathrm{M}_{\mathrm{W}}=7.2 ;[17,18]$ ); the 5 June, 1688 earthquake (I = XI MCS, $\left.\mathrm{M}_{\mathrm{w}}=7.1 ;[18,19]\right)$; and the $\mathrm{S}$. Anna earthquake of 26 July, 1805 ( $\mathrm{I}=\mathrm{X}$ MCS, $\mathrm{M}_{\mathrm{w}}=6.7 ;[18,20]$ Figure 1 ) whose epicentral area was the Bojano basin. This strong historical seismicity was characterized not only by a high and extensive level of damage, but also by widespread, both primary and secondary, environmental effects [20-22]. According to DISS database, the "Il Lago" Plain is located between two well-known seismogenic sources: Carpino-Le Piane to the NW and Bojano to the SE [23]. 


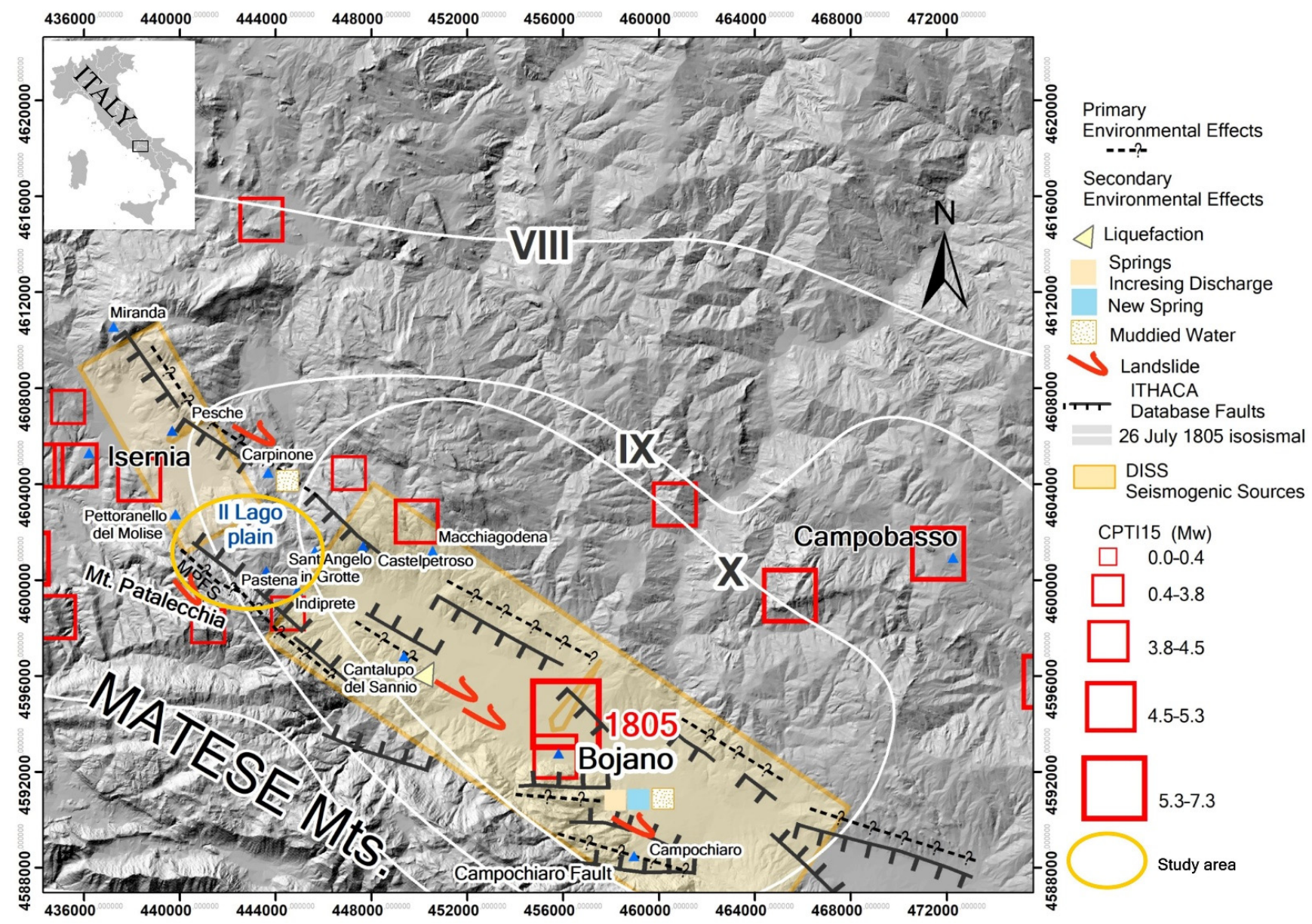

Figure 1. Seismotectonic sketch map of the study region: the study site of "Il Lago" Plain is the dark yellow ellipse; the historical earthquakes' epicenters are from CPTI15 [24] (red squares); the Scheme 23. (orange rectangular boxes); the isoseismals (MCS intensity scale) of the 1805 earthquake are from [20] (white solid lines); the primary coseismic fractures of the 1805 earthquake are from [22] (black dashed lines); the secondary coseismic effects of the 1805 earthquake, namely liquefaction, springs increasing discharge, new springs, muddied waters, and landslides, are from [22]. Easting and northing are UTM WGS 84.

The structural, geomorphological and macroseismic data suggest $[21,22,25,26]$ that the Quaternary normal fault segments in the Bojano area correspond to a system of capable faults (i.e., faults that can produce deformation and dislocation at the surface during strong seismic events) comparable to the systems responsible for the great recent earthquakes in the Apennines (e.g., Fucino 1915, Irpinia 1980, Amatrice Visso-Norcia 2016-2017).

Detailed studies on environmental effects generated by the strong 1805 earthquake $[19,21,22]$ showed that some coseismic surface faulting might have also occurred in correspondence with the "Il Lago" Plain. The normal fault bordering the plain to the SW is a poorly known structure, weakly expressed at the surface by small morphological scarps/warps (Figure 2). Indeed, some difficulties persist in defining the detailed faulting geometry (both at the surface and at depth) and type of the structures related to the 1805 earthquake. The only available information about the northern part of the 1805 seismic source derives from sparse paleosismological evidence [15,27].

Therefore, the "Il Lago" Plain, filled with young sediments that might preserve evidence related to Holocene surface faulting events, is a key location for understanding the seismic potential of the area. In this line, we investigated the subsurface of the northern portion of the 1805 fault system, bordering the "Il Lago" Plain, using low-frequency Ground Penetrating Radar (GPR) data supported by seismic tomography data. Seismic data yielded preliminary information on the underground structures and the dielectric 
permittivity of the subsoil. GPR data allowed a quick and detailed characterization of the fault geometry, with enhanced depth penetration and lateral resolution.

\section{Geological and Seismological Context}

\subsection{Regional Setting}

The tectonics of the Italian peninsula is driven by the Neogene-Quaternary kinematic evolution of the Mediterranean area. Since the Early-Middle Pleistocene, a severe $(\sim 7 \mathrm{~mm}$ /year) regional uplift coupled to a predominant NE-SW extension affected the inner sectors of the Southern Apennines [28,29]. NW-striking normal faults, which are parallel to the chain axis, developed in response to this extension. Active crustal extension is also expressed by focal mechanisms of strong earthquakes and geodetic data ([30-32] and references therein). The normal faults network dissecting the Southern Apennines axis consist of 5-10 km long, mostly NW-trending and NE-dipping, individual segments, forming complex systems up to $25-30 \mathrm{~km}$ long (e.g., [15,33] and references therein). Most of them show clear hints of activity, such as the offset of Quaternary continental deposits and the fresh exposure of bedrock fault planes. This was interpreted as mostly due to rapid exhumation during coseismic surface slip episodes occurred after the Last Glacial Maximum [34,35].

The Molise Apennines are characterized by a series of intermountain basins, of which the most northerly ones are the Isernia and Bojano basins (Figure 1). The evolution of these basins, starting at least from the Middle Pleistocene, was controlled by the NE-SW crustal extension [36-38], along a segmented system of active normal faults [15,16,33]. Similar to the normal fault segments that generated the 23 November 1980, Irpinia-Lucania earthquake, the Molise Apennines intermountain basins developed along a highly segmented fault array formed by $\mathrm{N}$ - to NE-dipping active normal faults $[15,16]$.

\subsection{The Bojano Basin Fault-System}

The above-mentioned tectonic regime favored the progressive development of fault slopes, well represented along the SW edge of the Bojano basin. The fault system of the "Bojano basin" consists of NW-SE normal synthetic and antithetic fault segments. They outcrop along the Matese Massif slopes and are also buried at the edges of the plain $[21,27,34,35]$. The buried faults acted as the main structure in the most ancient phases of the tectonic-sedimentary evolution of the area, causing the early phase of the Bojano basin opening and later transferring the tectonic activity to the piedmont faults. The NE-dipping system fault consists of five main segments ranging from 4 to $7 \mathrm{~km}$ for a total length of about $28 \mathrm{~km}$ (e.g., [15,16]). It includes the northeastern side of Mt. Patalecchia, the sector near the town of Cantalupo del Sannio, and the area between the towns of Bojano and Campochiaro (Figure 1). The outcropping Meso-Cenozoic bedrock is attributable to a depositional environment of carbonate platform/ramp and transition basin. It deposited in a stratigraphic interval ranging, in the study area, from the Upper Jurassic to the Middle Miocene. This is followed by calcareous-marly sediments of a neritic environment and by the calcarenitic-clayey-arenaceous sequences of foredeep from the Upper Tortonian to the Lower Messinian. The study area was involved in tertiary compressive deformation since the Upper Miocene; the folds and thrusts deriving from this tectonic phase were also subsequently displaced by strike-slip transfer faults. The present structural setting sees the carbonate bedrock sequence strongly dissected by variously oriented faults ( $N-S$, E-W, NE-SW). These were superimposed by normal faults with an Apennine orientation (NW-SE), which are the result of the Quaternary and ongoing crustal extension. They may reactivate the discontinuities inherited from the previous tectonic phase. Long-term Quaternary normal displacement in the central part of these NE-dipping fault segments is up to $900 \mathrm{~m}$, while Late Pleistocene to Holocene slip-rates have been estimated in 0.1 to $1.0 \mathrm{~mm} /$ year $[15,16,27]$.

The study area, the "Il Lago" Plain, is a minor local basin that closes towards NW the Bojano basin and is bordered by a buried active normal fault that is part of the Mt. 
Patalecchia Fault System (MPFS) ([39] and references therein) [40] (Figure 1). The total offset along the MPFS is at least $400 \mathrm{~m}$ [41]. The "Il Lago" area owes its name to a natural event that occurred during the 17th century, when the stream crossing it formed the lake. The final drainage of the plain was carried out in 1813 A.D. [42].

The Bojano basin, and its continuation towards the minor local "Il Lago" Plain, are filled by the Middle Pleistocene-Holocene slope-derived breccias, colluvial, fluviolacustrine and alluvial fan deposits [43-45]. The thickness of these successions reaches about $400 \mathrm{~m}$ in some sectors of the Bojano basin [46] and is not homogeneous within the basin due to an irregular trend of pre-Quaternary bedrock paleo-topography.

While for the Bojano basin a detailed stratigraphy is available, and the Middle to Late Pleistocene age of the fluvial-marshy and lacustrine-palustrine infilling is constrained based on borehole analyses and radiometric dating of tephra [15,47,48], for the "Il Lago" Plain, there is no published information on the sediments filling the recent plain. The Mt. Patalecchia mountainside is mainly constituted by Mesozoic calcareous successions, while in the foothills, the Cenozoic calcareous deposits crop up, composing the substratum of the lacustrine deposits of the "Il Lago" Plain (Figure 2).

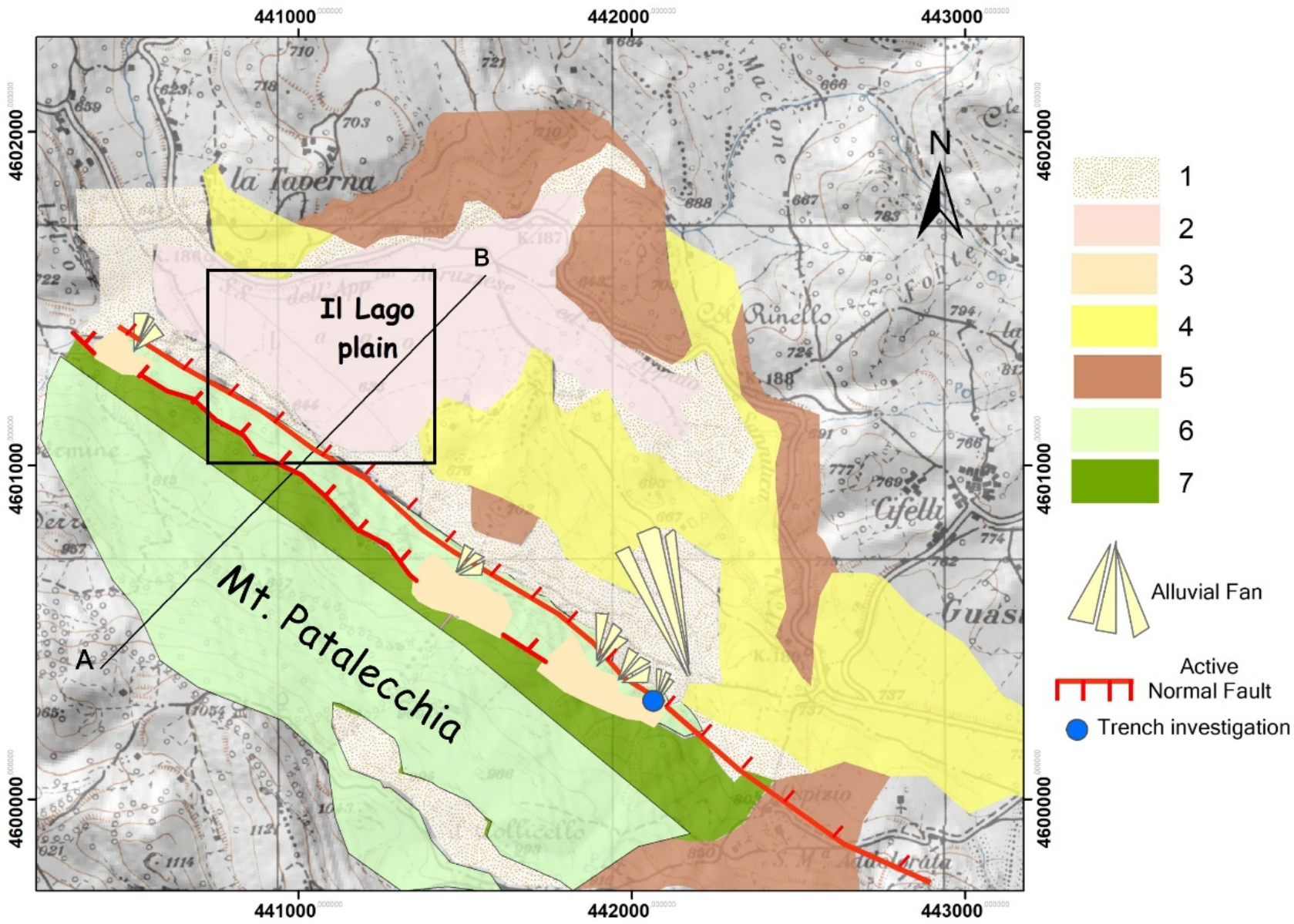

Figure 2. Geological sketch map of the investigated area: (1) colluvial and slope debris deposits (Holocene); (2) lacustrine deposits (Late Pleistocene to Holocene); (3) cemented limestone breccias (Middle to Late Pleistocene); (4) Calcarenites, calcilutites, and marly limestone (Serravallian-Tortonian); (5) marly limestone and marl (Oligocene-Burdigalian); (6) calcarenites and cherty limestones (Senonian-Turonian); and (7) Mesozoic limestone succession (Cenomanian-Early Turonian) modified after $[16,49]$. The black rectangle in the map is the area shown in Figure 3; the black line is the trace of the geological cross-section of Figure 14; the blue dot is the trench investigation site is from [27]. Easting and northing are UTM WGS 84. 

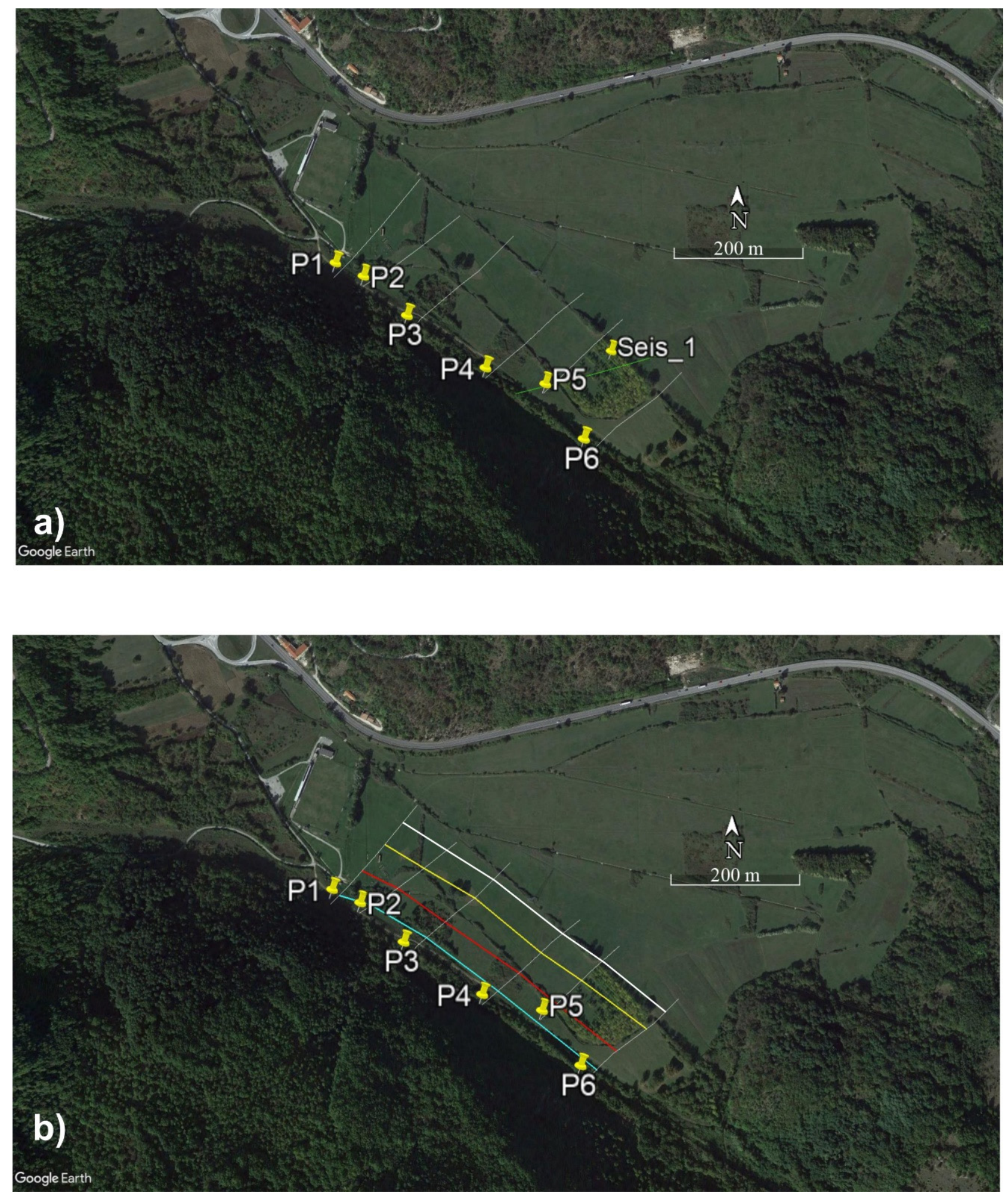

Figure 3. (a) Map of the seismic refraction (Seis_1) and GPR (from P1 to P6) profiles conducted at the "Il Lago" Plain (see the black box in Figure 2 for location); and (b) georeferenced localization of the identified structures associable to the fault system detected by GPR data. The solid light blue and yellow lines are the identified antithetic faults. The solid red and white lines are the identified synthetic faults (see Figure 13).

\subsection{Paleoseismicity and Historical Seismicity}

The evidence of Quaternary activity along the "Il Lago" fault segment was documented by the offset of Holocene alluvial deposits inside a paleoseismic trench, with evi- 
dence of at least two surface-rupturing seismic events occurred during the last 2600 years on the normal fault bordering the north-eastern slope of Mt. Patalecchia [27]. More specifically, the authors dated these two events between $3130 \pm 70$ and $2590 \pm 50$ years B.P.

Another strong seismic event dated to the early 3rd century B.C. (i.e., 280 B.C.) was identified by archaeoseismological evidence observed SE of the Bojano basin, along the Campochiaro fault (Figure 1) [50].

As mentioned, in historical times, the Bojano basin was the epicentral area of several high-magnitude seismic events: in 1456 [17,18] and in 1805 [18]) (Figure 1).

The December 1456 earthquakes (on the 5th and 30th), according to the authors of [48] causing at least 60,000 casualties, were certainly among the most catastrophic and powerful earthquakes occurred in Italy. Such earthquakes are related to either three or five different seismogenic sources located in a wide area spanning from the central to the Southern Apennines, with one of the sources located to the north of the Matese ridge [17,51,52]. The 1456 earthquake Imax reached the XI degree of the MCS scale $\left(\mathrm{M}_{\mathrm{W}}=7.2\right.$ [24]). Even though there is no historical description of the surface expression of the faults related to the 1456 earthquake, secondary ground effects (e.g., landslides, hydrological variations, fractures, liquefaction phenomena mostly related to ground shaking) were documented. Furthermore, the seismic sequence triggered a moderate tsunami in the harbor of Naples where some ships were damaged [53].

The 26 July, 1805 earthquake, known as the "St. Anna's earthquake", was another energetic and destructive historical event that struck the Bojano basin causing about 5000 causalities [20] (Figure 1). It was felt in the Molise and Campania regions, in more than 200 localities, with $\mathrm{I}_{0}=X \mathrm{MCS}$ and $\mathrm{M}_{\mathrm{w}}=6.7$ [24] reaching its maximum intensity, $\mathrm{I}_{\max }=$ XI MCS in Frosolone [20], nearly $20 \mathrm{~km}$ to the $\mathrm{E}$ of the town of Isernia, whose level of damage reached the X MCS. Unlike the 1456 earthquake, several primary coseismic effects on the natural environment were identified for the 1805 earthquake, based on the review of historical documents. Since these effects are particularly relevant for the present study, we describe them in detail in the next section.

Apart from the seismic events of 1805, this area was affected by low-magnitude, background, seismicity characterized by both sparse earthquakes and seismic sequences [54-56], such as the event of 1882 (with epicentral location in the Isernia area, $\mathrm{I}_{0}=\operatorname{VII}\left(\mathrm{M}_{\mathrm{W}}=5.2\right.$, [24]).

In the last decades, the instrumental seismicity of the Northern Matese area was characterized by low-energy swarms and sparse seismic events with maximum magnitudes of $4.0<\mathrm{M}_{1}<5.0$ [54,55,57-60]. The last earthquake of the area occurred on 16 January 2016 with $\mathrm{M}_{1} 4.1$, affecting an area located $\sim 10 \mathrm{~km} \mathrm{NE}$ of the Bojano basin (Figure 1).

\subsection{Environmental Effects of the 1805 S. Anna's Earthquake}

A detailed description of ground ruptures is reported in historical documents regarding the destructive 1805 earthquake [60-65]. Primary effects such as surface faulting, and secondary effects including hydrological anomalies, ground cracks, slope movements, ground settlements and tsunamis were observed [20-22,25,26,66-69] (Table 1 and Figure 1).

Surface ruptures were reconstructed along the synthetic normal faults bordering the Mt. Patalecchia fault segment [21]. Based on the isoseismal intensity distribution, environmental effects and paleoseismological data, some authors associated the 1805 earthquake to a seismogenic source located in the Bojano basin [21,25,38,66,69-71]. 
Table 1. The 26 July, 1805 earthquake-induced primary effects with contemporary descriptions of surface fault segments and ground cracks $([61,63-65])$.

\begin{tabular}{|c|c|c|c|c|}
\hline Location & Type & Historical Description & Ref. & Note \\
\hline $\begin{array}{l}\text { Miranda } \\
\text { S. Angelo in Grotte }\end{array}$ & $\begin{array}{c}\text { Surface } \\
\text { faulting/ground } \\
\text { crack }\end{array}$ & $\begin{array}{l}\text { "A very long fracture was surveyed } \\
\text { from Miranda, Pesche up to S. } \\
\text { Angelo in Grotte. Especially in the } \\
\text { upper mountain from Miranda to S. } \\
\text { Angelo in Grotte chasms were open } \\
\text { for about a half palm." }\end{array}$ & {$[61]$} & $\begin{array}{l}\text { One Neapolitan } \\
\text { palm }=26.3 \mathrm{~cm}\end{array}$ \\
\hline $\begin{array}{l}\text { Matese Mt. } \\
\text { Guardiaregia } \\
\text { Morcone } \\
\text { From Campobasso to Bussi } \\
\text { Isernia (Mt. Patalecchia) } \\
\text { Carpinone }\end{array}$ & $\begin{array}{c}\text { Surface } \\
\text { faulting/ground } \\
\text { crack }\end{array}$ & $\begin{array}{l}\text { "In the Matese and other mountains } \\
\text { of the county have made } \\
\text { considerable cracks. } \\
\text { Very evident and deep fractures with } \\
\text { offsets up to seven palms... you can } \\
\text { also see horrible cracks of stones in } \\
\text { the northern flank of Guardiareggia, } \\
\text { and in the southern flank of Isernia. } \\
\text { A third can be admired north of } \\
\text { Carpinone..." }\end{array}$ & {$[63]$} & Offset of about $150 \mathrm{~cm}$ \\
\hline $\begin{array}{c}\text { Pesche Carpinone Guardia } \\
\text { regia } \\
\text { Matese Mt } \\
\text { Salcito Trivento Montagano } \\
\text { Morcone }\end{array}$ & $\begin{array}{c}\text { Surface } \\
\text { faulting/ground } \\
\text { crack }\end{array}$ & $\begin{array}{l}\text { "An opening wider than a } \\
\text { Neapolitan palm, and more than } \\
\text { two miles long was found } \\
\text { throughout the back of the hill of } \\
\text { Pesche... Carpinone also had in its } \\
\text { surroundings two cracks, as still } \\
\text { Guardia Regia, ... The surface of } \\
\text { Mount Matese is all traced of } \\
\text { considerable cracks... Equally } \\
\text { considerable cracks were observed } \\
\text { in the lands of Salcito, Trivento, } \\
\text { Montagano, and Morcone..." }\end{array}$ & {$[64]$} & 1 mile $=1845.69 \mathrm{~m}$ \\
\hline Morcone & $\begin{array}{c}\text { Surface } \\
\text { faulting/ground } \\
\text { crack }\end{array}$ & $\begin{array}{l}\text { "Horrible chasms opened over a } \\
\text { length of about one-third of a mile, } \\
\text { some of which had the ground } \\
\text { overthrown at a height exceeding } \\
\text { two palms, and of which the width } \\
\text { was over three palms and } \\
\text { comparable the depth. These } \\
\text { fractures now can be seen from far } \\
\text { away, because the grass along the } \\
\text { crevasses is desiccated as it had been } \\
\text { on fire. In one such crevasse I } \\
\text { observed a pear tree, that, in that } \\
\text { moment [of the earthquake], lost all } \\
\text { its unripe fruits, threw many } \\
\text { branches to the ground and, of the } \\
\text { ones left, many are now desiccated. } \\
\text { In the same place the soil was } \\
\text { completely disturbed, as it had } \\
\text { excavated by innumerable moles." }\end{array}$ & {$[65]$} & $1 \mathrm{mile}=1845.69 \mathrm{~m}$ \\
\hline
\end{tabular}

Most ground effects were located within the VIII MCS isoseismal area [20] (Figure 1). About 100 seismically induced environmental effects allowed assessment of an intensity value $(\mathrm{I}=V-X)$ for 50 municipalities located in the near and far field area [26]. Based on the review of historical documents, and in agreement with geological investigations along the Bojano fault system $[25,27,66]$, it was possible to measure the surface rupture length $(40 \mathrm{~km})$ according to the methodology proposed in $[56,72,73]$ (and references therein). The length of the "macroseismic" surface faulting was estimated after joining the precise locations of fault ruptures corresponding to the end-to-end distance between the farthest locality points where fault ruptures were reported. In fact, several authors contemporary to the earthquakes $[61,63-65]$ described extensive ground ruptures with vertical displacements up to 1-1.5 m, in at least two localities, Morcone (Benevento district) and Guardiaregia (Isernia district; Figure 1), likely due to movements along a Holocene normal fault on the NE slopes of the Matese Massif $[15,16,21,22,26]$. The secondary effects triggered by the 
earthquake were: at least 26 landslides, mainly rock falls, topples, slumps, earth flows, and slump earth flows, and hydrological anomalies in 29 localities, mainly around Bojano (Biferno springs) and Mt. Matese. It is important to note the distribution of landslides vs. the earthquake fault: most of the landslides (88.5\%) occurred within a distance of $30 \mathrm{~km}$; the rest of them took place within a distance of about $80 \mathrm{~km}$; in particular, $23.0 \%$ of the total occurred in the epicentral area $(0-10 \mathrm{~km})$, distributed along the zone of coseismic faulting, and $65 \%$ were between 10 and $30 \mathrm{~km}$. Most landslides concentrated inside the intensity VII-X MCS isoseismal area (Figure 1). The distribution of hydrologic anomalies displays an almost linear decay away from the causative faults, with $90 \%$ of the effects within $40 \mathrm{~km}$ for the 1805 event [21,73]. Furthermore, small tsunami waves were reported in the Gulfs of Naples and Gaeta ([22] and references therein).

\section{Data and Methods}

In order to detect and characterize the detailed geometry of the buried faults along the SW border of "Il Lago" Plain, we performed a geophysical survey on the test site by means of seismic refraction and GPR methods (Figure 3).

Seismic tomography provides insights into the stratigraphy of the subsoil and the geometry of structures by analyzing the distribution of artificially generated elastic waves (e.g., $[10,74])$.

Ground Penetrating Radar (GPR) is an Electromagnetic (EM) geophysical methodology working at microwaves, with frequency range $10 \mathrm{MHz}-3 \mathrm{GHz}$, commonly used to investigate shallower buried structures. Processed data allow obtaining a spatial map of the subsurface in terms of electromagnetic properties and associate the "electromagnetic anomalies" to the presence and the shape of buried targets [75]. The choice of the working frequency results as a trade-off between the necessity to investigate deeper regions (pushing to lower frequencies) and the need to have higher resolution (pushing towards higher frequencies). In particular, as long as the increase in relative dielectric permittivity improves the achievable resolution, the presence of an electrical conductivity entails losses in the soil and limits the investigation depth. The use of GPR in engineering studies, to identify structures and sources in the shallow subsoil, is well-known (e.g., [76,77]). The usefulness of GPR in geological studies is affected by the limited obtainable depth of investigation. Previous studies detected indeed only the shallower portions of faults by $2 \mathrm{D}$ and 3D surveys (e.g., [78-87]). In this study, we exploited a low-frequency GPR, the Loza $2 \mathrm{~N}$ system working in the frequency band of tens of $\mathrm{MHz}$, already deployed in a few other applications, [88-93], to infer the geometry of buried faults at the depth of tens of meters.

In this work, we carried out a seismic refraction tomography for detecting the presence of the main geological structures of the basin and collect information in order to better constrain the interpretation of the B-scans acquired by GPR system along profiles almost parallel to the seismic one. The acquisition of six GPR parallel profiles permitted to identify the presence of a fault zone including vertical discontinuities (Figure 3).

\subsection{Seismic Refraction Data Acquisition and Processing}

The seismic profile is at the SW margin of the plain and strikes SW-NE (Seis_1 in Figure 3), nearly perpendicular to the probable direction of the fault system as reported in the ITHACA dataset [40] (Figure 1). The profile was recorded in June 2020 between the foot of Mt. Patalecchia and the plain, across the Holocene lacustrine and colluvial deposits that fill the plain.

We deployed 24 horizontal geophones with a frequency of $40 \mathrm{~Hz}$ spaced $10 \mathrm{~m}$ apart over a profile of $230 \mathrm{~m}$. Our seismic source consisted of a $15 \mathrm{~kg}$ sledgehammer that showed to produce clear first arrivals along the whole profile, thanks to the very good signal-tonoise ratio in the area (Figure 4). We performed nine hammer blows along the profile, with blows at G1, G3, G6, G9, G12, G15, G18, G21 and G24. 


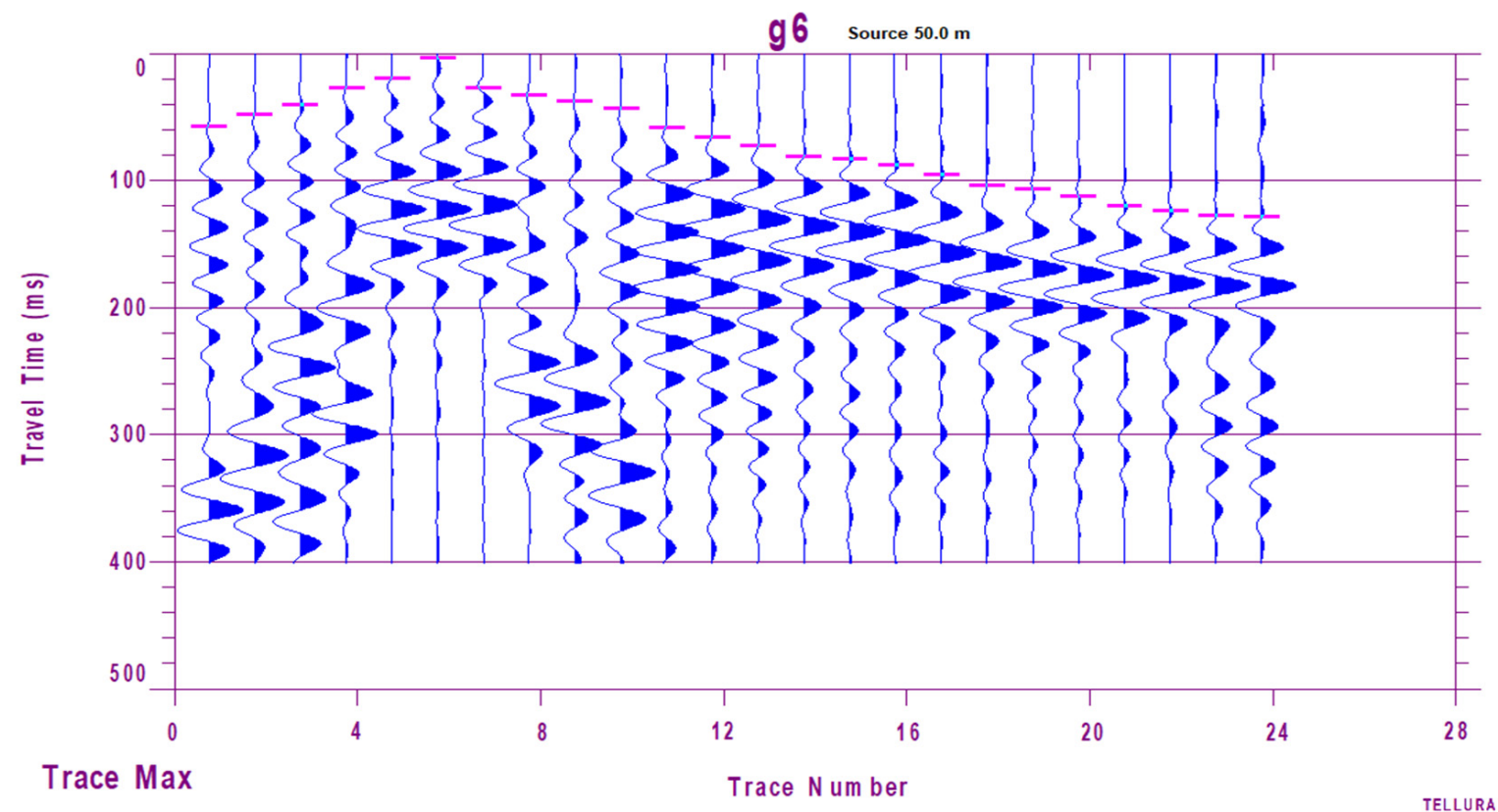

Figure 4. Example of first P-wave arrivals of the exploratory seismic tomography survey (profile Seis_1, see Figure 3) performed in the plain.

From data acquired along the seismic profile, we inverted the 216 first arrivals, previously handpicked on nine records (Figure 5).

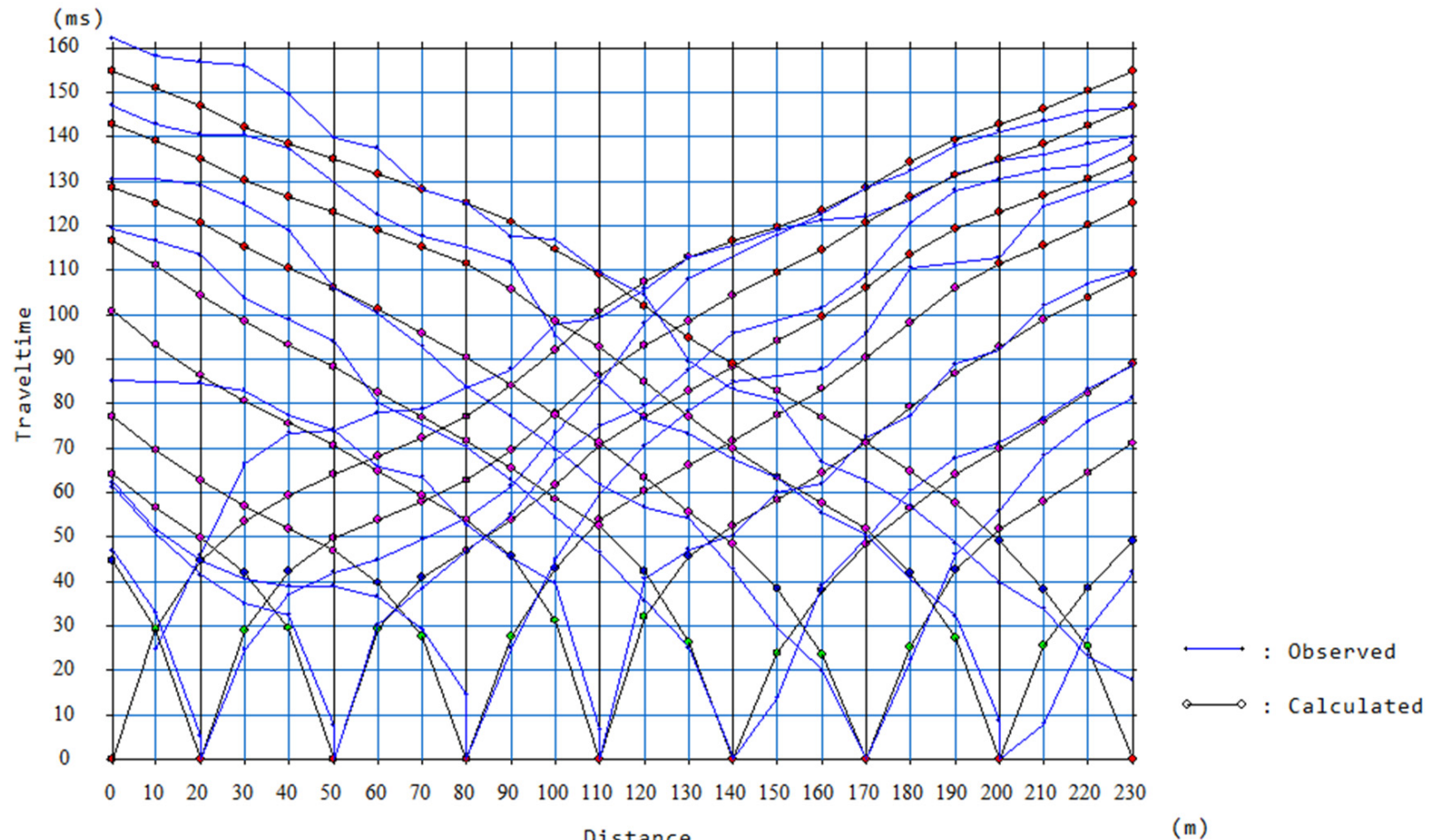

Figure 5. Time-distance plot of profile Seis_1. The presence of velocity lateral variations is clear between 70 and $80 \mathrm{~m}$ distance and around at 145-150 m distance.

The $\mathrm{V}_{\mathrm{p}}$ model was determined by a tomographic algorithm, by using a non-linear Least Squares method implemented in the software Plotrefa. This method starts with an initial velocity model (generally a layered model generated by a time-term inversion), 
and iteratively traces rays through the model with the goal of minimizing the RMS error between the observed and calculated travel times (RMS error: $11.84 \mathrm{~ms}$ ). The obtained $V_{p}$ model (Figure 6) shows a high-velocity area in the SW side of the profile with a clear and significant sub-vertical velocity variation at about $20-80 \mathrm{~m}$. We also depict a less abrupt sub-vertical velocity variation around $120-180 \mathrm{~m}$.

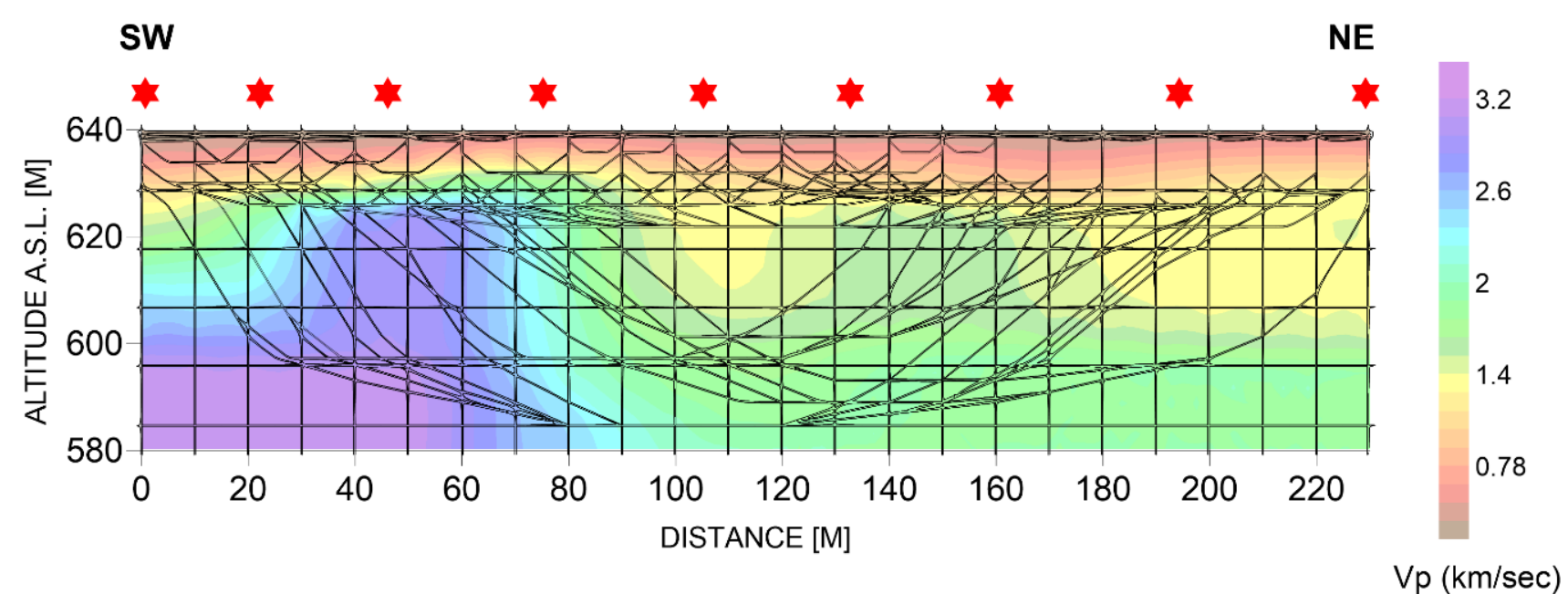

Figure 6. Results of the seismic tomography at the "Il Lago" Plain (profile Seis_1, Figure 3), with raytracing overlaid; the red stars are the shot positions.

Based on these preliminary seismic tomography results, we furtherly investigated the area by the GPR method by performing six high-resolution SW-NE profiles partially overlapping the seismic profile (Figure 3 ).

\subsection{GPR Data Acquisition and Processing}

In this study, the radargrams, also referred to as B-scan, were gathered by means of the Loza GPR system, which was designed especially for high-conductivity soils (wet clay, loam), at the Pushkov Institute of Terrestrial Magnetism, Ionosphere and Radio Wave Propagation (IZMIRAN) in relation with a planned space mission Mars '94 [93].

The GPR sensing principle is as follows: a transmitting (Tx) antenna radiates an electromagnetic signal into the probed medium, while a receiving $(\mathrm{Rx})$ antenna gathers the portion of energy reflected/backscattered by the electromagnetic perturbations into the medium and occurring into a fixed observation time window. Therefore, by moving $T x$ and $\mathrm{Rx}$ antennas along a line and by collecting, at each measurement point, the backscattered field as a function of the round-trip travel time, i.e., the signal propagation time along the path Tx antenna-target-Rx antenna, a 2D image of the surveyed scenario, referred to as a radargram, is obtained. The radargram provides a representation of the subsurface features, wherein localized objects appear as hyperbola while material interfaces as constant signals, and the depth, $\mathrm{z}$, of the targets is estimated by converting the round-trip travel time, $t$, according to the following relation:

$$
z=\frac{c t}{2 \sqrt{\varepsilon}}
$$

wherein $c=3 \times 10^{8} \mathrm{~m} / \mathrm{s}$ represents the light propagation velocity and $\varepsilon$ is the average relative dielectric permittivity of the investigated medium [76,93].

Loza GPR is equipped with two not-shielded monostatic antennas, one Tx and one $\mathrm{Rx}$, placed at the mutual distance of 6 and $10 \mathrm{~m}$, respectively, for generating radar pulses at the central frequencies of 25 or $15 \mathrm{MHz}$ [89]. The two antennas were moved along the profiles using a parallel (Figure 7) and/or an in-line array. 


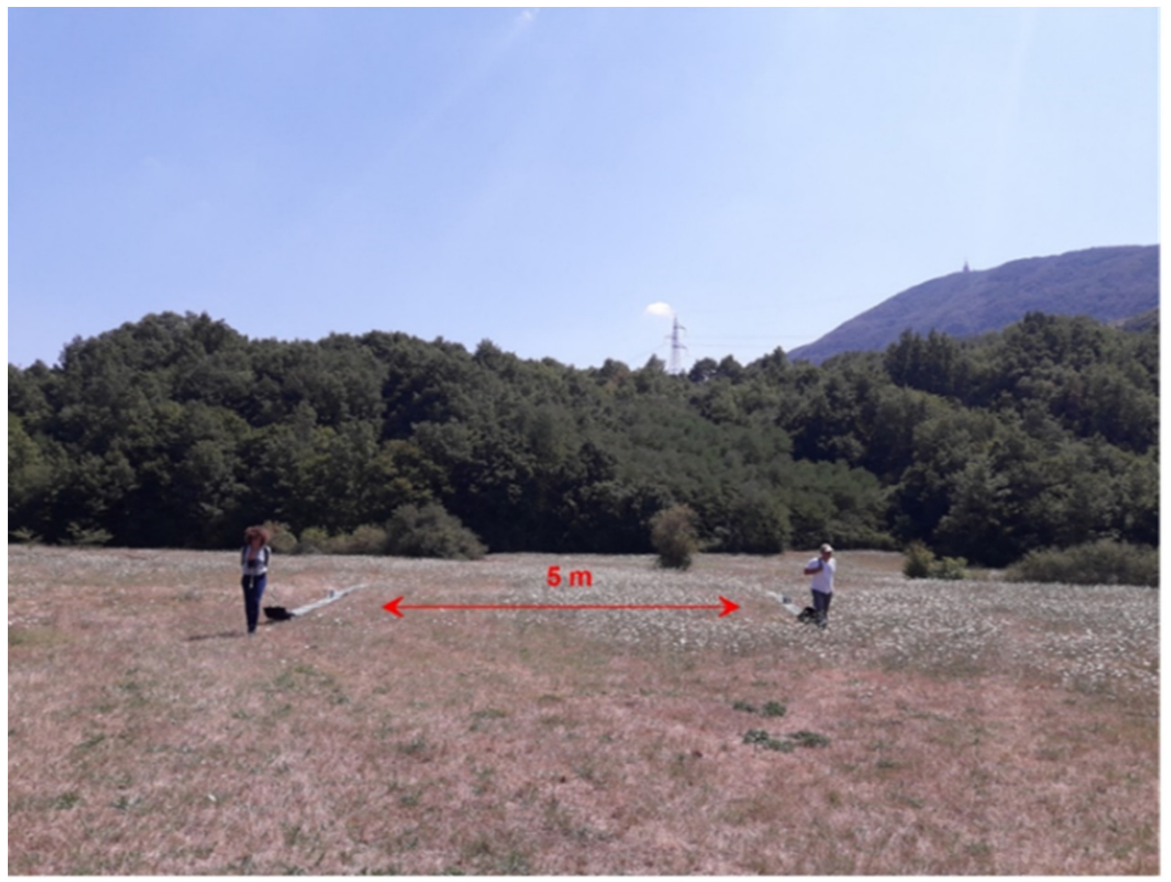

Figure 7. Parallel array of the low-frequency GPR survey at the "Il Lago" Plain; photo taken from the NE towards the SW looking Mt. Patalecchia.

In addition, the GPR systems consists of:

(i) a high-power transmitter unit of $15 \mathrm{kV}, 50 \mathrm{MW}$;

(ii) a receiving unit to record broadband pulses with direct signal digitization, without stroboscopic conversion and $120 \mathrm{~dB}$ energy dynamic;

(iii) two $\mathrm{Wu}-$ King antennas 6-15 $\mathrm{m}$ long without cable connection and with radio trigger placed on foils made of high-density polyethylene resistant to rubbing (Figure 7) that are resistively-loaded dipoles covered by a dielectric layer that avoids the dispersion of the transmitted signal;

(iv) a controller connected to the receiver unit through a coaxial shielded multipolar cable.

We collected six parallel approximately $200 \mathrm{~m}$ long GPR radargrams, named P1-P6, spaced about $150 \mathrm{~m}$ from each other. These profiles trend SW-NE, orthogonally to the main direction of the valley (see Figure 3). Table 2 reports the acquisition parameters adopted for each profile in terms of length, spatial step, and working frequency.

Table 2. Acquisition parameters of the GPR survey.

\begin{tabular}{cccccccc}
\hline ID Data & $\begin{array}{c}\text { Length } \\
(\mathbf{m})\end{array}$ & $\begin{array}{c}\text { Spatial Step } \\
\mathbf{( m )}\end{array}$ & $\begin{array}{c}\text { Frequency } \\
\mathbf{( M H z )}\end{array}$ & $\begin{array}{c}\text { Easting Start } \\
\text { (UTM-m) }\end{array}$ & $\begin{array}{c}\text { Northing Start } \\
\text { (UTM-m) }\end{array}$ & $\begin{array}{c}\text { Easting End } \\
\text { (UTM-m) }\end{array}$ & $\begin{array}{c}\text { Northing End } \\
\text { (UTM-m) }\end{array}$ \\
\hline P1 & 203 & 2.5 & 15 & $440,755.19$ & $4,601,386.77$ & $440,890.79$ & $4,601,538.72$ \\
P2 & 185 & 2.5 & 15 & $440,801.55$ & $4,601,373.14$ & $440,951.19$ & $4,601,479.89$ \\
P3 & 206 & 2.4 & 15 & $440,880.19$ & $4,601,312.10$ & $441,033.00$ & $4,601,446.72$ \\
P4 & 199 & 2.3 & 15 & $440,988.88$ & $4,601,231.02$ & $441,142.06$ & $4,601,359.67$ \\
P5 & 160 & 1.6 & 15 & $441,078.61$ & $4,601,207.34$ & $441,202.22$ & $4,601,319.15$ \\
P6 & 198 & 3.3 & 25 & $441,138.12$ & $4,601,115.96$ & $441,290.82$ & $4,601,233.27$ \\
\hline
\end{tabular}

Figure 8 shows the raw data (B-scans) and the corresponding average trace for each scan. It can be seen how the radargrams are affected by undesired components, such as the signal due to the direct coupling between the Tx and Rx antennas and the measurement noise, which affects the useful part of the collected signal. More specifically, in the first part of time window, up to about $400 \mathrm{~ns}$, each considered B-scan is affected by a strong 
phenomenon of direct coupling between the antennas, as also shown in the average traces in the right panels of Figure 8 and in their superposition in Figure 9.
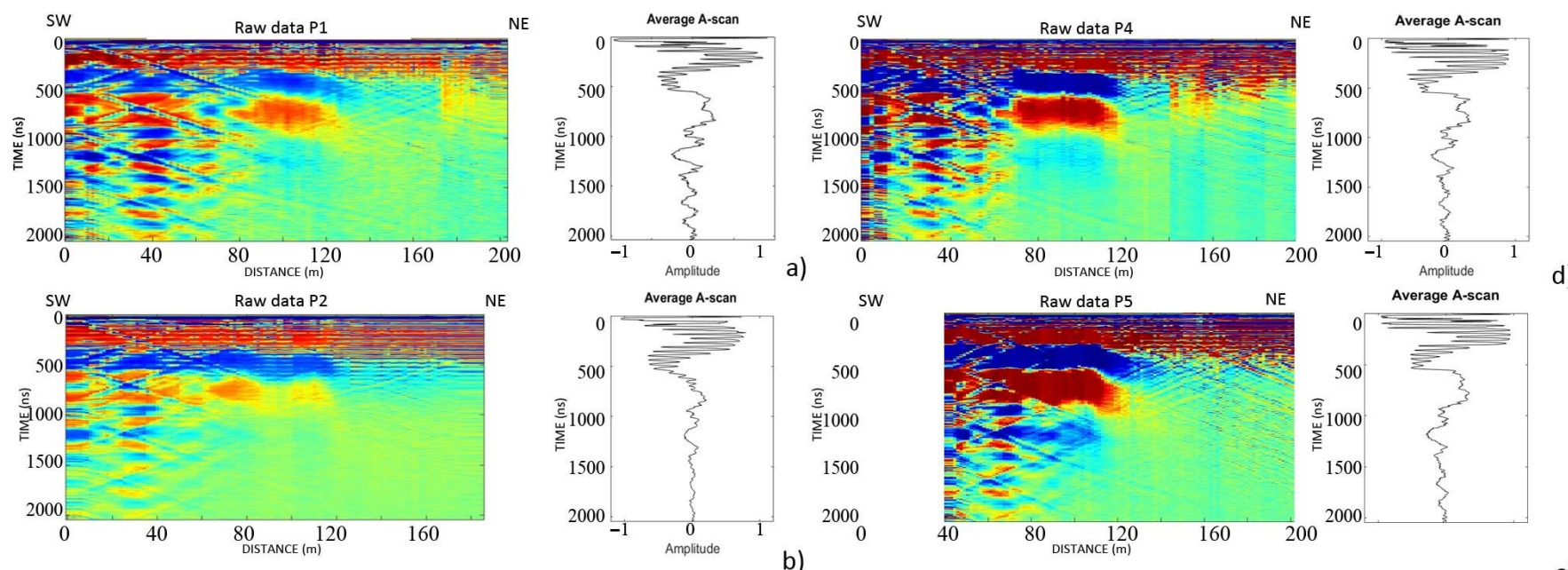

d)

b)
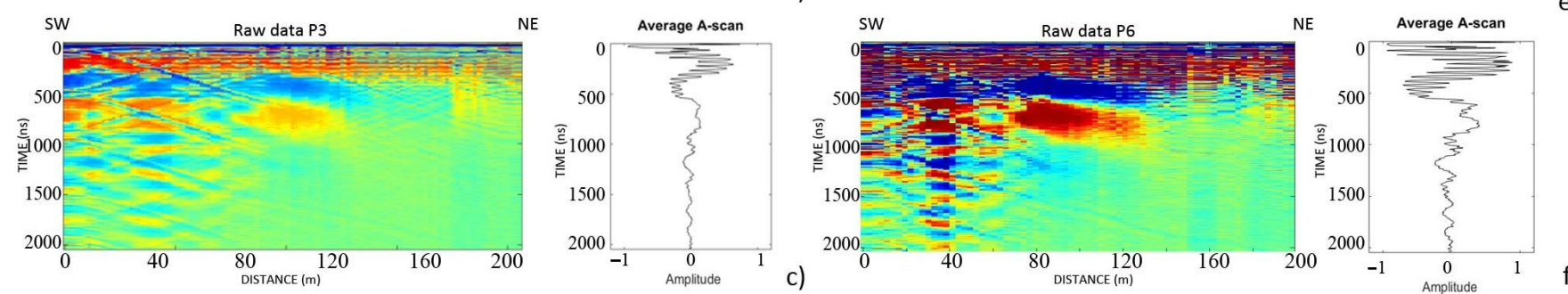

e)

Figure 8. Raw GPR radargrams with a relative average A-scan on the right side (P1-P6, see trace in Figure 3). The subplot to the right side of each profile shows the average trace of each radargram.

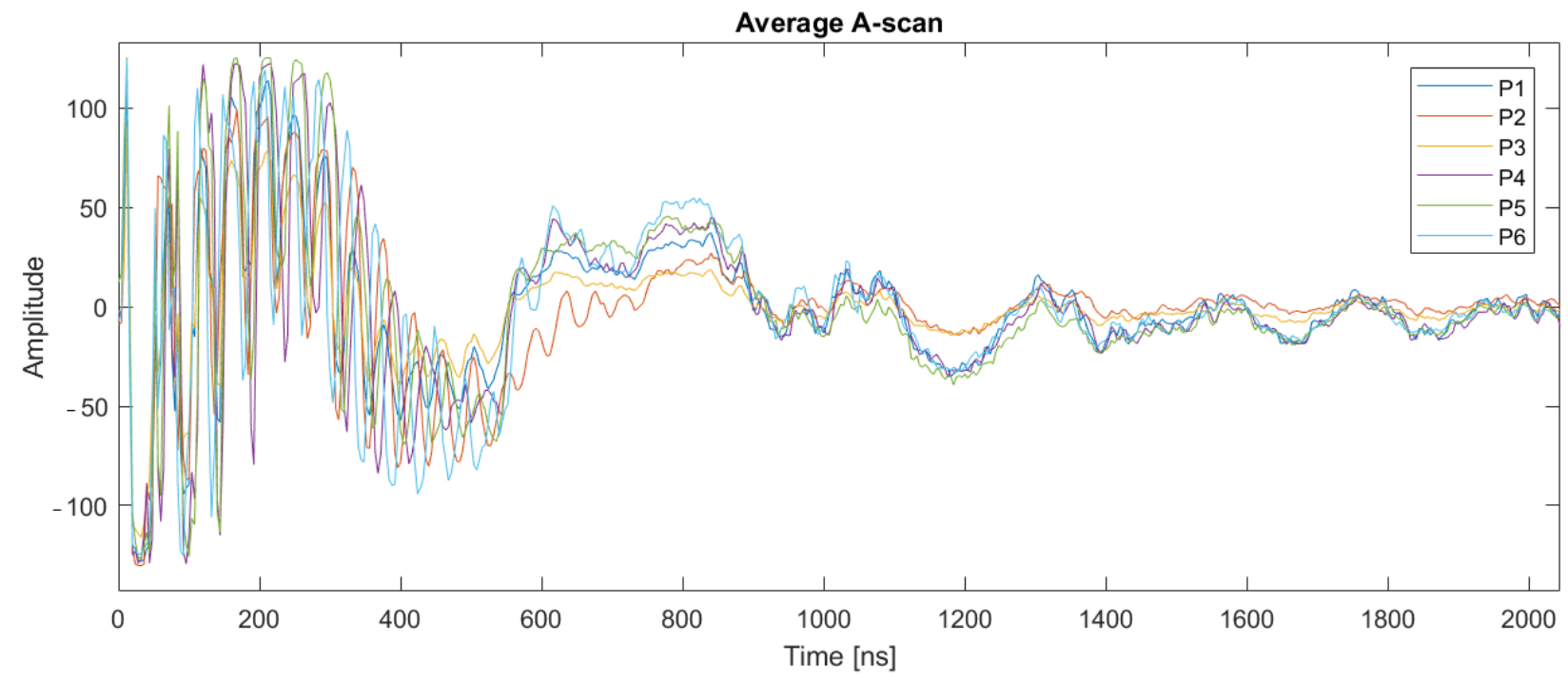

Figure 9. Superposition of the average A-scans.

Consequently, filtering procedures are necessary for reducing the effects of the undesired signals while improving the targets visibility. The choice of these procedures was driven by the specific surveyed scenario $[75,92,94,95]$.

Figure 10 shows the processing chain adopted to improve the interpretability of the considered GPR data. Specifically, the data processing involves the following procedures: 
1. The DeWOW procedure subtracts at each collected waveforms its mean value along the time axis.

2. The median filter, which allows removing noise from radargram and improving the results of later procedures [96].

3. The zero timing defines the actual starting time, $t_{0}$, of the observation time window.

4. The time gating selects the portion of the observation time window where the target response occurs and allows eliminating the direct antenna coupling, $t_{T G}$, as well as the clutter signal, i.e., all the signals occurring outside the portion of the time windows of interest.

5. Background (BKG) removal helps remove or mitigate the signal contributions due to antenna coupling, air-material interface, and (undesired) horizontal reflectors.

6. Topographic correction inserts the real altitude of each acquired A-Scan and georeference the radargrams.

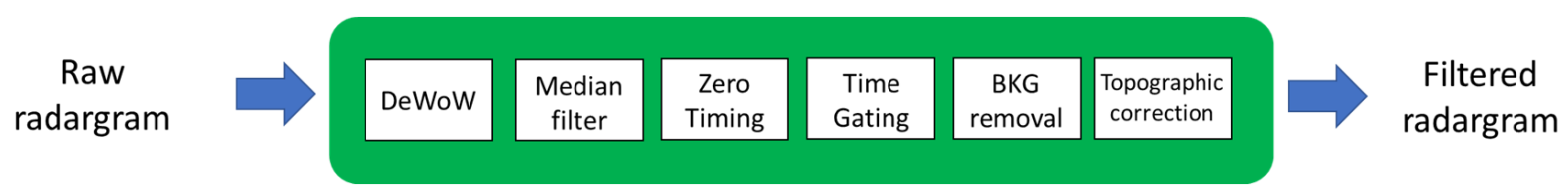

Figure 10. The flowchart shows GPR data processing steps.

In this case study, the observation time window of each radargram is 2044 ns, discretized by 512 time-samples. Furthermore, on the obtained radargrams, we performed zero timing by setting $t_{0}=16 \mathrm{~ns}$ and time gating as $t_{T G}=100 \mathrm{~ns}$. As mentioned above and confirmed by the superposition of the average A-scans in Figure 9, the first part of the signal is affected by a strong direct coupling of antennas. For this reason, we applied the BKG removal procedure to remove this constant signal in the interval from 100 to $400 \mathrm{~ns}$. Finally, we performed the two-way time-depth conversion by means of Equation (1) by assuming the relative dielectric permittivity $\varepsilon=10$. It is worth noticing that this value was chosen by exploiting the information from the seismic acquisition about the depth of high-velocity area (Figure 6).

\section{Results}

As mentioned above, the analysis on seismic data showed two areas with sub-vertical P-velocity variations, at 20-80 and 120-180 m. Regarding velocity values, we depicted a low velocity layer $\left(0.3<\mathrm{V}_{\mathrm{P}}<1 \mathrm{~km} / \mathrm{s}\right)$ and a layer with intermediate velocities $\left(\mathrm{V}_{\mathrm{P}} \cong 1.4 \mathrm{~km} / \mathrm{s}\right)$. Immediately below these layers, we identified another layer with medium-high velocity values $\left(1.6<\mathrm{V}_{\mathrm{P}}<2.2 \mathrm{~km} / \mathrm{s}\right)$ and high-velocity layers $\left(\mathrm{V}_{\mathrm{P}}>2.6 \mathrm{~km} / \mathrm{s}\right)$.

We interpret the depicted velocity variations to be caused by subvertical systems of faults, showing two horst and graben decametric structures, with NE-dipping synthetic and SW-dipping antithetic faults (Figure 11).

The GPR survey was carried out in July 2020 to confirm the information provided by the seismic survey thanks to the acquisition of data along profiles almost parallel to the seismic one. In this way, it was possible to identify the path of the fault along the overall length of the Il Lago Plain, and to achieve information about the shallower layers of the underground.

Figure 12 shows the six filtered radargram obtained by means of the data processing chain described in Section 3. The filtered data allow identifying three main areas, highlighted by three black dot-dashed rectangles (a-c in each panel of Figure 12), with strong reflections due to variations of the dielectric permittivity of the subsoil. More specifically, on the SW side of each filtered data section, we observe the reflective area (a) with a depth-to-the top of about $10 \mathrm{~m}$ (630 a.l.s.) and a lateral extension of about $25 \mathrm{~m}$. This GPR anomaly ends with a new discontinuity that could be associated with the presence of a second change in the geological condition (black dashed rectangle b). Then, we note a third 
anomalous area between the distances of $100-130 \mathrm{~m}$ where a third geological structure is expected (black dashed rectangle c). The sequence of the three main anomalies $(a-c)$ placed at a limited distance generally smaller than $50 \mathrm{~m}$ is well kept for all the radargrams acquired in the investigated foothills. Indeed, the results are similar despite the radargrams are distant up to $0.5 \mathrm{~km}$, as in the cases of P1 and P6 that are the outer investigation lines.

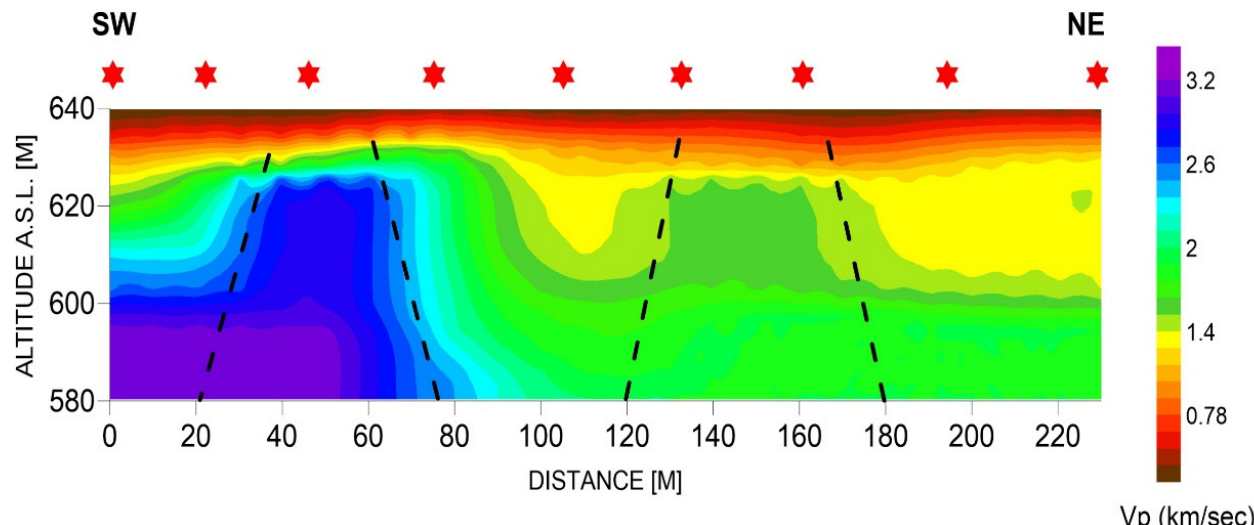

Figure 11. Results of profile Seis_1 (see Figure 3) with the detection of inferred position of faults (black dashed lines).
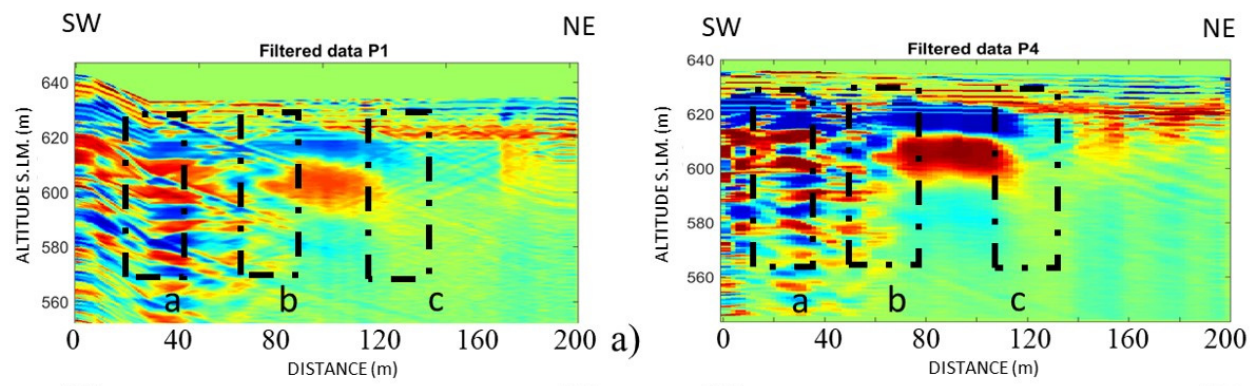

d)
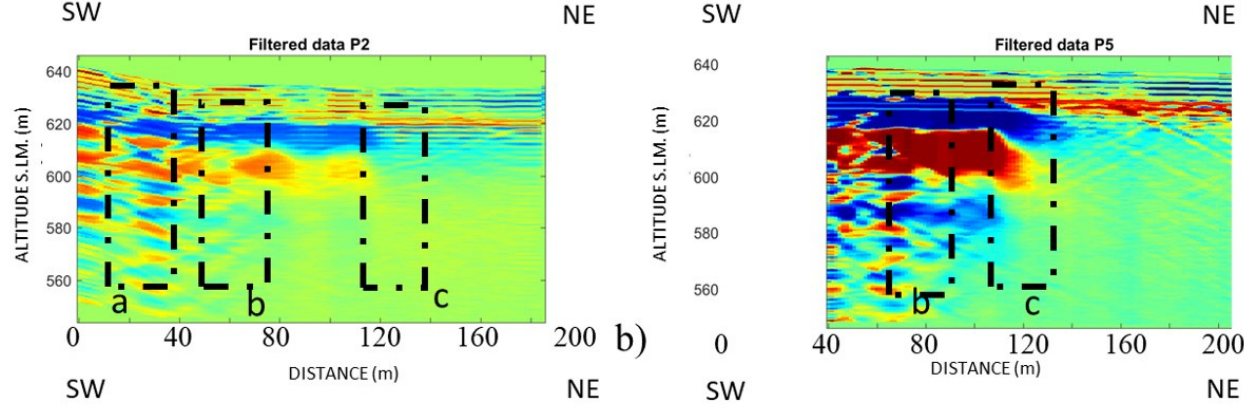

e)
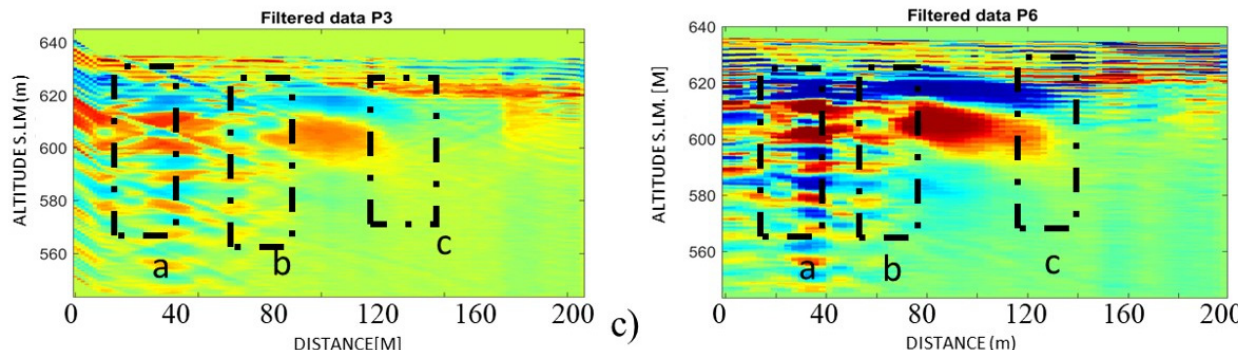

Figure 12. (a-f) Filtered data of each considered GPR profile (P1-P6, see trace in Figure 3). The black dot-dashed rectangles $(\mathbf{a}-\mathbf{c})$ highlight the variations of the electromagnetic response recorded along the profiles imputable to the presence of the expected geological structures. 
The geophysical contrast observed in all the GPR filtered data matches quite well with the sub-vertical synthetic and antithetic structures identified by the seismic data (Profile Seis_1 in Figure 3)

We note that the anomalies detected in the NE side of the profiles are not as clear as the ones located on the SW side of the profiles. This is probably due to the strong noise affecting the GPR data and the saturation of the signal in the first part of the time window ( $<500 \mathrm{~ns}$ ), likely related to the presence of clay and loamy soils. Thanks to the information provided by seismic data that show a high-velocity area on the SW side of profile Seis_1 with top at $20 \mathrm{~m}$ depth, the dielectric permittivity of the soils placed above the basement rocks was constrained to the value of $\varepsilon=10$.

The correlation between geophysical results and geological data is important for a reliable interpretation in the areas with buried active faults, such as the "Il Lago" Plain. Our interpretative cross section based on seismic and geological data [49] (Figure 13) shows a sub-vertical NE-dipping normal fault, located starting from $630 \mathrm{~m}$ a.s.l. displacing the deposits of the plain horst and graben structure controlled by antithetical faults. We also see a SW dipping fault system that forms a horst and graben structure controlled by antithetical faults. Another horst and graben structure can be inferred on the NE side of the profile.

NE
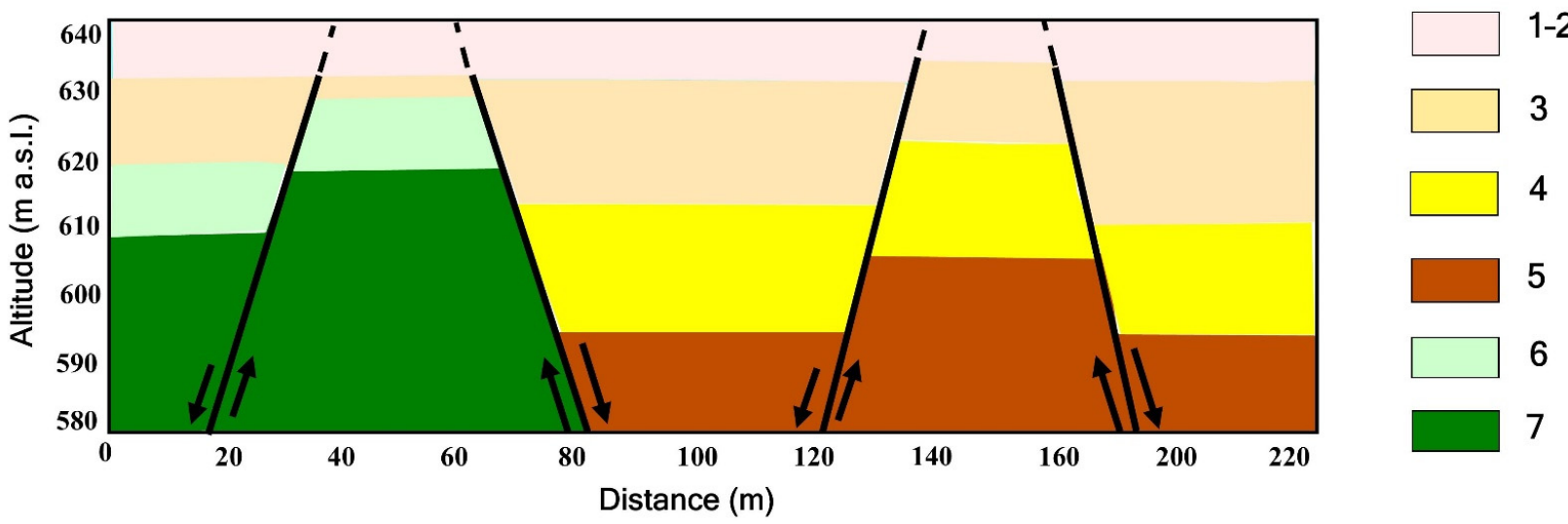

Figure 13. Geological interpretation along the Seis_1 profile (see location in Figure 3a): black dashed lines show the identified synthetic and antithetic normal faults and black arrows indicate the direction of displacement. Legend: (1-2) Slope and lacustrine deposits (Late Pleistocene-Holocene); (3) cemented limestone breccias (Middle-Late Pleistocene); (4) calcarenites, calcilutites, and marly limestone (Serravallian-Tortonian); (5) marly limestone and marl (Oligocene-Burdigalian); (6) calcarenites and cherty limestones (Senonian-Turonian); and (7) mesozoic limestone succession (Cenomanian-Early Turonian). Wehere merged geological units 1 and 2 of Figure 1 in one geological unit.

We interpret the layer with the lowest $\mathrm{V}_{\mathrm{P}}$ value $\left(0.3<\mathrm{V}_{\mathrm{P}}<1 \mathrm{~km} / \mathrm{s}\right)$ as the Late Pleistocene-Holocene slope and colluvial-lacustrine deposits of the plain. The layer with intermediate velocities $\left(\mathrm{V}_{\mathrm{P}} \cong 1.4 \mathrm{~km} / \mathrm{s}\right)$ is probably associable with breccias filling for about $30 \mathrm{~m}$ the graben. Immediately below these deposits, we identified another layer with medium-high velocity values $\left(1.6<\mathrm{V}_{\mathrm{P}}<2.2 \mathrm{~km} / \mathrm{s}\right)$ that we interpret as calcarenites, calcilutites, marls, and marly limestones. The structure with the highest velocity value $\left(\mathrm{V}_{\mathrm{P}}>2.6 \mathrm{~km} / \mathrm{s}\right)$ corresponds most likely to more cemented calcarenites and limestones and the Mesozoic carbonate bedrock. These high-velocity areas match with strongly reflective areas of the GPR signal (Figure 12d).

\section{Discussion}

Surface faulting associated with the 1805 earthquake is reported in paleoseismic trench sites SE of the plain in $[15,27]$. However, detailed definition of the northern termination of earthquake rupture is still debated. This is due to a combination of factors: (i) the post-earthquake surveys, although carried out with appreciable descriptive effort, report 
coseismic surface ruptures that are tens of $\mathrm{km}$ apart, and with opposite dips [22]; (ii) some interpretation of the seismogenic sources in the area of Bojano and the NE side of the Matese Massif are rather simplified and are unlikely to comply with the complexity of the fault segmentation [16]; (iii) a faint constraint to the geometry of the source is supplied by the scarce and sparse instrumental seismicity that occurred over the last decades and by geodetic data [30-32]; and (iv) the local geomorphic and structural setting does not allow the straightforward detection of unambiguous surface breaks, as already observed in other small tectonic basins in the Southern Apennines (e.g., [8]).

In this work, we aimed at characterizing the buried structures of the area by seismic refraction tomography supported by the GPR methodology. The interpretative geological cross section based on geological and seismic data (Figure 13) shows four sub-vertical normal faults, two faults dipping towards the SW and two faults dipping towards the NE. They displace the deposits of the plain towards the north-eastern side of the basin (Figure 13). The top to the faults is at about $10 \mathrm{~m}$ depth (starting from $630 \mathrm{~m}$ a.s.l.). The inferred system forms a horst and graben structure. The GPR profiles confirmed this interpretation especially for NE-dipping normal fault, as shown, in all radargrams, where trongly reflective areas match with the structure identified by the seismic data (Figure 13). The GPR and seismic refraction data highlighted the spatial continuity of the two buried fault systems along the southwestern side of the "Il Lago Plain" for a length of about $0.5 \mathrm{~km}$ (Figure 3b).

The width of the SW graben likely reflects the depth at which the dip of the Mt. Patalecchia master fault changes to a lower angle (Figure 14). Indeed, the subsurface geometry of the horst and graben structure associated with the master normal fault bounding Mt. Patalecchia suggests a decreasing fault dip, from the $60^{\circ}$ dip observed in the field to ca. $45-50^{\circ}$ (Figure 13; Figure 14), as observed in similar gravity-graben structures for instance along capable normal faults in Nevada [97,98] or in Southern Tibet ([99] and references therein).

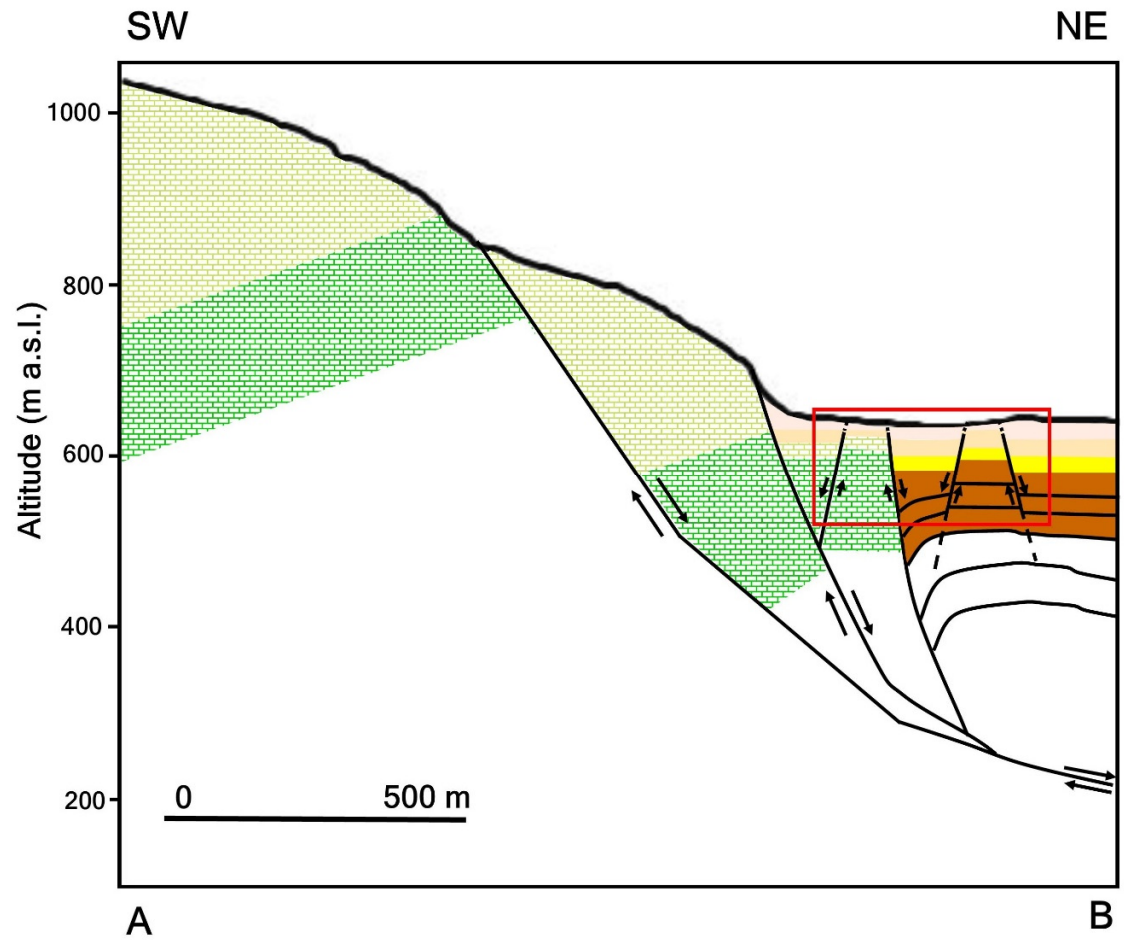

Figure 14. Geological cross section along $\mathrm{AB}$ (whose trace and geological units are shown in Figure 2); the red box is the interpreted profile of Figure 13. Based also on data from [16,49], we interpret the shallow horst and graben structure beneath the SW border of the Plain as due to the listric geometry of the Mt. Patalecchia fault system. 


\section{Conclusions}

We carried out a study across an active normal fault at the "Il Lago" Plain (Pettoranello del Molise, Southern Italy) by newly acquired geophysical data and literature geological data. We used low frequency GPR methods combined with seismic tomography methods. As is known, the usefulness of traditional GPR techniques in geological studies is affected by the limited obtainable depth of investigation. Previous studies indeed detected only the shallowest portions of faults (e.g., $[87,88])$. Conversely, our study demonstrates the optimal potential of combined seismic and deep GPR surveys for investigating buried faults at depth of tens of meters (down to $60 \mathrm{~m}$ in this study). This can be specifically applied to young structures that, despite their probable seismogenic potential, have not yet developed mature geomorphic features or are buried under thick sequences of recent deposits. Even though the "Il Lago" Plain is a small basin within the Bojano fault system, our study adds insights into the MPFS, recognizing four buried sub-vertical antithetic and synthetic normal faults that form horst and graben structures below the plain filling. Our results suggest that the application of these geophysical techniques may allow a quick fault-detection for an accurate choice of paleoseismological trench sites. In fact, GPR and seismic data allowed inferring, from different clues and evidence, the spatial continuity of fault systems previously unknown. This result is crucial given the seismotectonic importance of the Bojano basin, for improving the knowledge of the Holocene paleoseismological history.

The geophysical evidence of Late Pleistocene to Holocene displacement beneath "Il Lago" Plain strongly suggests that recent sedimentation rates at this site are larger than the vertical component of normal faulting rate. A similar result has been already documented for instance in the San Gregorio Magno Plain, where paleoseismic evidence of Holocene surface faulting was studied with exploratory trenching across the 1980 earthquake surface ruptures $[8,100]$. Therefore, our investigations do not rule out that the 1805 surface faulting also affected the "Il Lago" Plain, as suggested by historical literature (Table 1). This hypothesis however needs to be verified or falsified by future trench investigations.

Author Contributions: Conceptualization, R.N., V.P., A.M.M. and S.P.; methodology, D.D., F.S., L.C., and G.L.; validation, R.N., V.P., D.D., S.P., F.S., L.C., G.L. and A.M.M.; and investigation, R.N. and D.D. All authors discussed the data, their processing and the models, and co-wrote the manuscript. All authors have read and agreed to the published version of the manuscript.

Funding: This research received no external funding.

Institutional Review Board Statement: Not applicable.

Informed Consent Statement: Not applicable.

Data Availability Statement: Not applicable.

Acknowledgments: We thank Franz Livio for the discussion on the structural setting of the Patalecchia Fault. The authors are indebted with Marco Caciagli for making available his fieldwork data on the "Il Lago" Plain, Germana Gaudiosi for her support on seismological data, Eleonora Di Marzo for earlier processing and interpretation of GPR data, Maurizio Fedi for discussion on the GPR method, and Pavel Morozov (Pushkov Institute of Terrestrial Magnetism, Ionosphere and Radio Wave Propaga-tion, Troitsk, Moscow, Russia) and Aleksandr Pitvorak for their comments on the low-frequency ground penetrating radar. The authors are grateful to three anonymous reviewers for their constructive remarks.

Conflicts of Interest: The authors declare no conflict of interest.

\section{References}

1. Roberts, G.P.; Michetti, A.M. Spatial and temporal variations in growth rates along active normal fault systems: An example from The Lazio-Abruzzo Apennines, central Italy. J. Struct. Geol. 2004, 26, 339-376. [CrossRef]

2. Jackson, J.; Leeder, M. Drainage systems and the development of normal faults: An example from Pleasant Valley, Nevada. J. Struct. Geol. 1994, 16, 1041-1059. [CrossRef]

3. Bull, W.B. Tectonically Active Landscapes; Wiley Blackwell: Hoboken, NJ, USA, 2009; 320p, ISBN 978-1-4051-9012-1. 
4. Burbank, D.W.; Anderson, R.S. Tectonic Geomorphology, 2nd ed.; Wiley Blackwell: Hoboken, NJ, USA, 2011; p. 460. ISBN 978-1-444-33887-4.

5. Ascione, A.; Nardò, S.; Mazzoli, S. The MS 6.9, 1980 Irpinia Earthquake from the Basement to the Surface: A Review of Tectonic Geomorphology and Geophysical Constraints, and New Data on Post-seismic Deformation. Geosciences 2020, 10, 493. [CrossRef]

6. Galli, P. Roman to Middle Age Earthquakes Sourced by the 1980 Irpinia Fault: Historical, Archaeoseismological, and Paleoseismological Hints. Geosciences 2020, 10, 286. [CrossRef]

7. Bello, S.; De Nardis, R.; Scarpa, R.; Brozzetti, F.; Cirillo, D.; Ferrarini, F.; Di Lieto, B.; Arrowsmith, R.; Lavecchia, G. Fault pattern and seismotectonic style of the Campania-Lucania 1980 earthquake (Mw 6.9, Southern Italy): New multidisciplinary constraints. Front. Earth Sci. 2021, 8, 652. [CrossRef]

8. Aiello, G.; Ascione, A.; Barra, D.; Munno, R.; Petrosino, P.; Ermolli, E.R.; Villani, F. Evolution of the late Quaternary San Gregorio Magno tectono-karstic basin (southern Italy) inferred from geomorphological, tephrostratigraphical and palaeoecological analyses: Tectonic implications. J. Quat. Sci. 2007, 22, 233-245. [CrossRef]

9. Galli, P.; Peronace, E. New paleoseismic data from the Irpinia Fault. A different seismogenic perspective for southern Apennines (Italy). Earth Sci. Rev. 2014, 136, 175-20110. [CrossRef]

10. Improta, L.; Ferranti, L.; De Martini, P.M.; Piscitelli, S.; Bruno, P.P.; Burrato, P.; Civico, R.; Giocoli, A.; Iorio, M.; D'Addezio, G.; et al. Detecting young, slow-slipping active faults by geologic and multidisciplinary high-resolution geophysical investigations: A case study from the Apennine seismic belt, Italy. J. Geophys. Res. 2010, 115, B11307. [CrossRef]

11. Everett, M.E. Near-Surface Applied Geophysics; Cambridge University Press: Cambridge, UK, 2013; $403 p$, ISBN 9781107018778.

12. Villani, F.; Pucci, S.; Civico, R.; De Martini, P.M.; Nicolosi, I.; D’Ajello Caracciolo, F.; Carluccio, R.; Di Giulio, G.; Vassallo, M.; Smedile, A.; et al. Imaging the structural style of an active normal fault through multi-disciplinary geophysical investigation: A case study from the Mw 6.1, 2009 L'Aquila earthquake region (central Italy). Geophys. J. Int. 2015, 200, 1676-1691. [CrossRef]

13. Luiso, P.; Paoletti, V.; Nappi, R.; Gaudiosi, G.; Cella, F.; Fedi, M. Testing the value of a multi/scale gravimetric analysis in characterizing active fault geometry at hypocentral depths: The 2016/2017 central Italy seismic sequence. Ann. Geophys. 2018, 61, DA558. [CrossRef]

14. Luiso, P.; Paoletti, V.; Nappi, R.; La Manna, M.; Cella, F.; Gaudiosi, G.; Fedi, M.; Iorio, M. A multidisciplinary approach to characterize the geometry of active faults: The example of Mt. Massico, Southern Italy. Geophys. J. Int. 2018, $213,1673-1681$. [CrossRef]

15. Galli, G.; Giaccio, B.; Messina, P.; Peronace, E.; Amato, V.; Naso, G.; Nomade, S.; Pereira, A.; Piscitelli, S.; Bellanova, J.; et al. Middle to Late Pleistocene activity of the northern Matese Fault System (southern Apennines, Italy). Tectonophysics 2017, 699, 61-81. [CrossRef]

16. Ferrarini, F.; Boncio, P.; De Nardis, R.; Pappone, G.; Cesarano, M.; Aucelli, P.P.C.; Lavecchia, G. Segmentation pattern and structural complexities in seismogenic extensional setting: The north Matese Fault System (central Italy). J. Struct. Geol. 2017, 95, 93-112. [CrossRef]

17. Meletti, C.; Patacca, E.; Scandone, P.; Figliuolo, B. Il terremoto del 1456 e la sua interpretazione nel quadro sismotettonico dell'Appennino meridionale. In Il Terremoto del 1456; Figliuolo, B., Ed.; Osservatorio Vesuviano e Istituto Italiano di Studi Filosofici, Storia e Scienze della Terra: Napoli, Italy, 1988; Volume 1, pp. 71-108.

18. Locati, M.; Camassi, R.; Rovida, A.; Ercolani, E.; Bernardini, F.; Castelli, V.; Caracciolo, C.H.; Tertulliani, A.; Rossi, A.; Azzaro, R.; et al. DBMI15, the 2015 Version of the Italian Macroseismic Database; Istituto Nazionale di Geofisica e Vulcanologia: Rome, Italy, 2016. [CrossRef]

19. Serva, L. The earthquake of 5 June, 1688 in Campania. In Atlas of Isoseismal Maps of Italian Earthquakes; Postpischl, D., Ed.; CNR-PFG: Rome, Italy, 1985; Volume 114, pp. 44-47.

20. Esposito, E.; Luongo, G.; Marturano, A.; Porfido, S. Il terremoto di S. Anna del 26 Luglio 1805. Mem. Soc. Geol. Ital. 1987, 37, 171-191.

21. Porfido, S.; Esposito, E.; Vittori, E.; Tranfaglia, G.; Michetti, A.M.; Blumetti, M.; Ferreli, L.; Guerreri, L.; Serva, L. Areal distribution of ground effect induced by strong earthquakes in the southern Apennines (Italy). Surv. Geophys. 2002, 23, 529-562. [CrossRef]

22. Porfido, S.; Esposito, E.; Vittori, E.; Tranfaglia, G.; Guarrieri, L.; Pece, R. Seismically induced ground effects of the 1805,1930 and 1980 earthquakes in the Southern Apennines (Italy). Boll. Soc. Geol. Ital. J. Geosci. 2007, 126, 333-346.

23. DISS Working Group. Database of Individual Seismogenic Sources (DISS), Version 3.2.1; A Compilation of Potential Sources for Earthquakes Larger than M 5.5 in Italy and Surrounding Areas; Istituto Nazionale di Geofisica e Vulcanologia: Rome, Italy, 2018; Available online: http:/ / diss.rm.ingv.it/diss / (accessed on 1 February 2021). [CrossRef]

24. Rovida, A.; Locati, M.; Camassi, R.; Lolli, B.; Gasperini, P. CPTI15, the 2015 Version of the Parametric Catalogue of Italian Earthquakes; Istituto Nazionale di Geofisica e Vulcanologia: Rome, Italy, 2016; 33p. [CrossRef]

25. Michetti, A.M.; Blumetti, A.M.; Esposito, E.; Ferreli, L.; Guerrieri, L.; Porfido, S.; Serva, L.; Vittori, E. Earthquake ground effects and seismic hazard assessment in Italy examples from the Matese and Irpinia areas, Southern Apennines. Active Fault Research for the New Millennium. In Proceedings of the Hokudan Symposium and School on Active Faulting, Hokudan Town, Japan, 17-26 January 2000; pp. 279-284.

26. Serva, L.; Esposito, E.; Guerrieri, L.; Porfido, S.; Vittori, E.; Comerci, V. Environmental effects from five historical earthquakes in Southern Apennines (Italy) and macroseismic intensity assessment. Contribution to INQUA EEE Scale Project. Quat. Intern. 2007, 173, 30-44. [CrossRef] 
27. Blumetti, A.M.; Caciagli, M.; Di Bucci, D.; Guerrieri, L.; Michetti, A.M.; Naso, G. Evidenze di fagliazione superficiale olocenica nel bacino di Bojano (Molise). In Proceedings of the $19^{\circ}$ Meeting GNGTS, Rome, Italy, 7-9 November 2000; pp. 12-15.

28. Westaway, R. Quaternary uplift of Southern Italy. J. Geophys. Res. 1993, 98, 21741-21772. [CrossRef]

29. Cinque, A.; Patacca, E.; Scandone, P.; Tozzi, M. Quaternary kinematic evolution of the Southern Apennines. Relationship between surface geological features and deep lithospheric structures. Ann. Geof. 1993, 36, 249-260.

30. Esposito, A.; Galvani, A.; Sepe, V.; Atzori, S.; Brandi, G.; Cubellis, E.; De Martino, P.; Dolce, M.; Massuccia, A.; Obrizzo, F.; et al . Concurrent deformation processes in the Matese massif area (Central-Southern Apennines, Italy). Tectonophysics 2020, 774, 228234. [CrossRef]

31. Carafa, M.M.C.; Galvani, A.; Di Naccio, D.; Kastelic, V.; Di Lorenzo, C.; Miccolis, S.; Sepe, V.; Pietrantonio, G.; Gizzi, C.; Massucci, A.; et al. Partitioning the Ongoing Extension of the Central Apennines (Italy): Fault Slip Rates and Bulk Deformation Rates from Geodetic and Stress Data. J. Geophys. Res. Solid Earth 2020, 125, e2019JB018956. [CrossRef]

32. Ferranti, L.; Palano, M.; Cannavò, F.; Mazzella, M.E.; Oldow, J.S.; Gueguen, E.; Mattia, M.; Monaco, C. Rates of geodetic deformation across active faults in southern Italy. Tectonophysics 2014, 621, 101-122. [CrossRef]

33. Sgambato, C.; Faure Walker, J.; Mildon, Z.; Roberts, G.P. Fault/shear-zone system geometry and Coulomb pre-stress heterogeneity provides insights into stress-loading variability for earthquake faults. Sci. Rep. 2020, 10, 12724. [CrossRef] [PubMed]

34. Giraudi, C.; Frezzotti, M. Paleoseismicity in the Gran Sasso Massif (Abruzzo, central Italy). Quat. Int. 1995, 25, 81-93. [CrossRef]

35. Benedetti, L.; Manighetti, I.; Gaudemer, Y.; Finkel, R.; Malavieille, J.; Pou, K.; Arnold, M.; Aumaître, G.; Bourlès, D.; Keddadouche, K. Earthquake synchrony and clustering on Fucino faults (Central Italy) as revealed from in situ $36 \mathrm{Cl}$ exposure dating. J. Geophys. Res. Solid Earth 2013, 118, 4948-4974. [CrossRef]

36. Corrado, S.; Di Bucci, D.; Leschiutta, I.; Naso, G.; Trigari, A. La tettonica quaternaria della piana di Isernia nell'evoluzione strutturale del settore molisano. Il Quaternario 1997, 10, 609-614.

37. Di Bucci, D.; Naso, G.; Corrado, S.; Villa, I.M. Growth, interaction and seismogenetic potential of coupled active normal faults (Isernia Basin, central-southern Italy). Terra Nova 2005, 17, 44-55. [CrossRef]

38. Galli, P.; Galadini, F. Disruptive earthquakes revealed by faulted archaeological relics in Samnium (Molise, southern Italy). Geophys. Res. Lett. 2003, 30, 1266. [CrossRef]

39. Galderisi, A.; Galli, P.; Mazzoli, S.; Peronace, E. Kinematic constraints of the active northern Matese Fault System (southern Italy). Boll. Geofis. Teor. Ed. Appl. 2017, 58, 285-302. [CrossRef]

40. Ithaca Working Group. ITHACA (ITaly HAzard from CApable Faulting), A Database of Active Capable Faults of the Italian Territory. Version December 2019. ISPRA Geological Survey of Italy. Web Portal. Available online: http://sgi2.isprambiente.it/ ithacaweb/Mappatura.aspx (accessed on 1 February 2021).

41. De Corso, S.; Scrocca, D.; Tozzi, M. Geologia dell'anticlinale del Matese e implicazioni per la tettonica dell'Appennino molisano. Boll. Soc. Geol. Ital. 1998, 117, 419-441.

42. Paolino, A.; Cogo, F. Da Pectoranum a Pettoranello di Molise; CEP Eds.: Monteroduni, Italy, 1990; pp. 1-95.

43. GEMINA. Il bacino del Tammaro. In Ligniti e Torbe dell'Italia Continentale; Ilte: Torino, Italy, 1963; pp. 123-125.

44. Vezzani, L.; Ghisetti, F.; Festa, A. Carta Geologica del Molise; scale 1:100,000, 1 sheet; S.EL.CA: Firenze, Italy, 2004.

45. ISPRA. Note Illustrative della Carta Geologica d'Italia alla Scala 1:50.000, 2014, Foglio 405 “Campobasso"; Servizio Geologico Nazionale: Roma, Italy, 2014.

46. Bernabini, M.; Eva, C.; Nicolich, R.; Baranello, S.; Cercato, M.; De Ferrari, R.; Ferretti, G.; Pellegrino, P.; Scapillati, N. Microzonazione sismica del comune di Bojano (CB). In Proceedings of the $28^{\circ}$ GNGTS Convegno, Trieste, Italy, 16-19 November 2009; pp. 262-265.

47. Amato, V.; Aucelli, P.P.C.; Cesarano, M.; Jicha, B.; Lebreton, V.; Orain, R.; Pappone, G.; Petrosino, P.; Russo Ermolli, E. Quaternary evolution of the largest intermontane basin of the Molise Apennine (central-southern Italy). Rend. Lincei 2014, 25, 197-216. [CrossRef]

48. Amato, V.; Aucelli, P.P.C.; Cesarano, M.; Cifelli, F.; Leone, N.; Mattei, M.; Russo Ermolli, E.; Petrosino, P.; Rosskopf, C.M. The infill timing of a quaternary intermontane basin: New chrono-stratigraphic and palaeoenvironmental data by a $900 \mathrm{~m}$ deep borehole from Campochiaro (central-southern Apennine, Italy). In Proceedings of the Geophysical Research Abstracts, EGU General Assembly, Wien, Austria, 17-22 April 2016.

49. Caciagli, M. Analisi della Tettonica Attiva Lungo la Struttura del M. Patalecchia Tra i Bacini d'Isernia e Bojano. Tesi di Laurea in Science Geologiche; La Sapienza: Roma, Italy, 1997; p. 112. (In Italian)

50. Galli, P.; Galadini, F.; Capini, S. Analisi archeosismologiche nel santuario di Ercole di Campochiaro (Matese). Evidenze di un terremoto distruttivo sconosciuto ed implicazioni sismotettoniche. Il Quat. Ital. J. Quat. Sci. 2002, 15, 151-163.

51. Magri, G.; Molin, D. Il Terremoto del dicembre 1456 nell'Appennino Centromeridionale; Comitato Nazionale Energia Nucleare: Rome, Italy, 1984; p. 180. (In Italian)

52. Fracassi, U.; Valensise, G. Unveiling the sources of the catastrophic 1456 multiple earthquake: Hints to an unexplored tectonic mechanism in southern Italy. Boll. Seism. Soc. Am. 2007, 97, 725-748. [CrossRef]

53. Maramai, A.; Brizuela, B.; Graziani, L. The Euro-Mediterranean tsunami catalogue. Ann. Geophys. 2014, 57, 1-26. [CrossRef]

54. Milano, G.; Di Giovambattista, R.; Alessio, G. Earthquake swarms in the Southern Apennines chain (Italy): The 1997 seismic sequence in the Sannio-Matese mountains. Tectonophysics 1999, 306, 57-78. [CrossRef] 
55. Chiarabba, C.; De Gori, P.; Mele, F.M. Recent seismicity of Italy: Active tectonics of the central Mediterranean region and seismicity rate changes after the Mw 6.3 L'Aquila earthquake. Tectonophysics 2015, 638, 82-93. [CrossRef]

56. Branno, A.; Esposito, E.; Luongo, G.; Marturano, A.; Porfido, S.; Rinaldis, V. The largest earthquakes of the Appennines, Southern Italy. In Proceedings of the International Symposium on Engineering Geology Problems in Seismic Areas, IAEG-AIGI, Bari, Italy, 13-14 April 1986; Volume 4, pp. 3-14.

57. Alessio, G.; Godano, C.; Gorini, A. A low magnitude seismic sequence near Isernia (Molise, central Italy) in January 1986. Pure Appl. Geophys. 1990, 134, 243-260. [CrossRef]

58. Vilardo, G.; Nappi, R.; Petti, P.; Ventura, G. Fault geometries from the space distribution of the 1990-1997 Sannio-Benevento earthquakes: Inferences on the active deformation in Southern Apennines. Tectonophysics 2003, 363, 259-271. [CrossRef]

59. Milano, G.; Di Giovanbattista, R.; Ventura, G. The 2001 seismic activity near Isernia (Italy): Implications for the seismictectonics of the Central-Southern Appennines. Tecnophysics 2005, 401, 167-178. [CrossRef]

60. ISIDe Working Group INGV. Italian Seismological Instrumental and Parametric Database; INGV: Roma, Italy, 2015. Available online: http:/ / iside.rm.ingv.it/iside/standard/index.jsp (accessed on 1 February 2021).

61. Fortini, P. Della cause de' terremoti e loro effetti. Danni di quelli sofferti dalla città di Isernia fino a quello de' 26 luglio 1805; Sardelli, T., Ed.; Marinelli Editore: Isernia, Italy, 1984; p. 65.

62. Iadone, P. Relazione dettagliata di tutto ciò che ha rapport all'accaduto per causa del tremuoto della sera de' 26 luglio corrente anno 1805, in questa città di Cajazzo, e sua diocesi, conformemente all'istruzione ricevute per tal' oggetto con dispaccio di 5 agosto. Colloquio sulle scienze della terra in onore di Nicola Covelli 1805. Ass. Storica del Caratino 1805, 8, 33-66.

63. Poli, G.S. Memoria sul Tremuoto de' 26 Luglio del Corrente Anno 1805; Ed. Orsino: Napoli, Italy, 1806; p. 225.

64. Pepe, G. Ragguaglio Historico-Fisico del Tremuoto Accaduto nel Regno di Napoli la Sera de 26 Luglio 1805; Giacomo, S., Ed.; Domenico Sangiacomo: Napoli, Italy, 1806; p. 174.

65. Capozzi, G. Memoria sul Tremuoto Avvenuto nel Contado di Molise nella Sera de 26 Luglio dell'Anno 1805; Independently Published: Benevento, Italy, 1834.

66. Guerrieri, L.; Scarascia Mugnozza, G.; Vittori, E. Analisi stratigrafica e geomorfologica della conoide tardo-quaternaria di Campochiaro ed implicazioni per la conca di Bojano in Molise. Il Quaternario 1999, 12, 237-247.

67. Michetti, A.M.; Esposito, E.; Guerrieri, L.; Porfido, S.; Serva, L.; Tatevossian, R.; Vittori, E.; Audemard, F.; Azuma, T.; Clague, J.; et al. Intensity Scale ESI 2007. Mem. Descr. Carta Geol. Ital. 2007, 74, 7-54.

68. Serva, L.; Vittori, E.; Comerci, V.; Esposito, E.; Guerrieri, L.; Michetti, A.M.; Mohammadioun, B.; Porfido, S.; Tatevossian, R.E. Earthquake Hazard and the Environmental Seismic Intensity (ESI) Scale. Pure Appl. Geophys. 2016, 173, 1479-1515. [CrossRef]

69. Cucci, L. Insights into the geometry and faulting style of the causative faults of the M6.7 1805 and M6.7 1930 earthquakes in the Southern Apennines (Italy) from coseismic hydrological changes. Tectonophysics 2019, 751, 192-211. [CrossRef]

70. Cucci, L.; D’Addezio, G.; Valensise, G.; Burrato, P. Investigating seismogenic faults in Central and Southern Apennines (Italy): Modeling of fault-related landscape features. Ann. Geofis. 1996, 39, 603-618.

71. Shebalin, N.V. Macroseismic data as information on source parameters of large earthquakes. Phys. Earth. Planet. Inter. 1972, 6, 316-323. [CrossRef]

72. Esposito, E.; Luongo, G.; Petrazzuoli, S.M.; Porfido, S. Damage scenarious introduced by the major seismic events from XV to XIX century in Naples city with particular references to the seismic response. In Proceedings of the 10th World Conference on Earthquake Engeenering, Madrid, Spain, 19-24 July 1992; pp. 1075-1080.

73. Esposito, E.; Pece, R.; Porfido, S.; Tranfaglia, G. Hydrological anomalies connected to earthquakes in Southern Apennines (Italy). Nat. Hazards Earth Syst. Sci. 2001, 1, 137-144. [CrossRef]

74. Bruno, P.P.; Castiello, A.; Improta, L. Ultrashallow seismic imaging of the causative fault of the 1980, M6.9, southern Italy earthquake by pre-stack depth migration of dense wide-aperture data. Geophys. Res. Lett. 2010, 37, L19302. [CrossRef]

75. Catapano, I.; Gennarelli, G.; Ludeno, G.; Soldovieri, F.; Persico, R. Ground-Penetrating Radar: Operation Principle and Data Processing. In Wiley Encyclopedia of Electrical and Electronics Engineering; Webster, J.G., Ed.; Wiley \& Sons: Hoboken, NJ, USA, 2019; pp. 1-23. [CrossRef]

76. Capozzoli, L.; De Martino, G.; Polemio, M.; Rizzo, E. Geophysical techniques for monitoring settlement phenomena occurring in reinforced concrete buildings. Surv. Geophys. 2020, 41, 575-604. [CrossRef]

77. Rizzo, E.; Capozzoli, L.; De Martino, G.; Grimaldi, S. Urban Geophysical approach to characterize the subsoil of the main square in San Benedetto del Tronto town (Italy). J. Eng. Geol. 2019, 257, 105133. [CrossRef]

78. Green, A.G.; Gross, R.; Holliger, K.; Horstmeyer, H.; Baldwin, J. Results of 3-D georadar surveying and trenching the San Andreas fault near its northern landwardlimit. Tectonophysics 2003, 368, 7-23. [CrossRef]

79. Gross, R.; Green, A.G.; Horstmeyer, H.; Holliger, K.; Baldwin, J. 3-D georadar images of an active fault: Efficient data acquisition, processing and interpretation strategies. Subsurf. Sens. Technol. Appl. 2003, 4, 19-40. [CrossRef]

80. Jewell, C.J.; Bristow, C.S. GPR studies in the Piano di Pezza area of the Ovindoli-Pezza Fault, Central Apennines, Italy: Extending paleoseismic trench investigations with high resolution GPR profiling. Near Surf. Geophys. 2006, 3, 65. [CrossRef]

81. Vanneste, K.; Verbeeck, K.; Petermans, T. Pseudo-3D imaging of a low-slip-rate active normal fault using shallow geophysical methods: The Geleen fault in the Belgian Mass River valley. Geophysics 2008, 73, B1-B9. [CrossRef]

82. Christie, M.; Tsoflias, G.P.; Stockli, D.F.; Black, R. Assessing fault displacement and off-fault deformation in an extensional tectonic setting using 3-D groundpenetrating radar imaging. J. Appl. Geophys. 2009, 68, 9-16. [CrossRef] 
83. Pauselli, C.; Federico, C.; Frigeri, A.; Orosei, R.; Barchi, M.R.; Basile, G. Ground penetrating radar investigations to study active faults in the Norcia Basin (Central Italy). J. Appl. Geophys. 2010, 72, 39-45. [CrossRef]

84. McClymont, A.F.; Green, A.G.; Kaiser, A.; Horstmeyer, H.; Langridge, R. Shallow fault segmentation of the Alpine fault zone, New Zealand revealed from 2- and 3-D GPR surveying. J. Appl. Geophys. 2010, 70, 343-354. [CrossRef]

85. Carpentier, S.F.A.; Green, A.G.; Langridge, R.; Boschetti, S.; Doetsch, J.; Abächerli, A.N.; Horstmeyer, H.; Finnemore, M. Flower structures and Riedel shears at a step over zone along the Alpine Fault (New Zealand) inferred from 2-D and 3-D GPR images. J. Geophys. Res. 2012, 117, B02406. [CrossRef]

86. Ercoli, M.; Pauselli, C.; Frigeri, A.; Forte, E.; Federico, C. “Geophysical paleoseismology” through high resolution GPR data: A case of shallow faulting imaging in Central Italy. J. Appl. Geophys. 2013, 90, 27-40. [CrossRef]

87. Ercoli, M.; Pauselli, C.; Frigeri, A.; Forte, E.; Federico, C. 3-D GPR data analysis for high-resolution imaging of shallow subsurface faults: The Mt Vettore case study (Central Apennines, Italy). Geophys. J. Int. 2014, 198, 609-621. [CrossRef]

88. Kopeikin, V.V.; Kuznetsov, V.D.; Morozov, P.A.; Popov, A.V.; Berkut, A.I.; Merkulov, S.V.; Alexeev, V.A. Ground penetrating radar investigation of the supposed fall site of a fragment of the Chelabinsk meteorite in Lake Chebarkul'. Geochem. Int. 2013, 51, 575-582. [CrossRef]

89. Buzin, V.; Edemsky, D.; Gudoshnikov, S.; Kopeikin, V.; Morozov, P.; Popov, A.; Prokopovich, I.; Skomarovsky, V.; Melnik, N.; Berkut, A.; et al. Search for Chelyabinsk Meteorite Fragments in Chebarkul Lake Bottom (GPR and Magnetic Data). J. Telecommun. Inf. Technol. 2017, 69-78. [CrossRef]

90. Prokopovich, I.; Edemsky, A.D.; Popov, P.; Morozov, P.A. GPR Survey of Fortification Objects on Matua Island. In Proceedings of the 17th International Conference on Ground Penetrating Radar (GPR), Rapperswil, Switzerland, 18-21 June 2018; IEEE Xplore. pp. 1-4. [CrossRef]

91. Rezaei, A.; Hassani, H.; Moarefvand, P.; Golmohammadi, A. Determination of unstable tectonic zones in C-North deposit, Sangan, NE Iran using GPR method: Importance of structural geology'. J. Min. Environ. 2019, 10, 177-195. [CrossRef]

92. Daniels, D.J. Ground penetrating radar. In Encyclopedia of RF and Microwave Engineering; Wiley \& Sons, Inc.: Hoboken, NJ, USA, 2005. [CrossRef]

93. Kopeikin, V.V.; Morozov, P.A.; Edemskiy, F.D.; Edemskiy, D.E.; Pavloskii, B.R.; Sungurov, Y.A. Experience of GPR Application in Oil-and-Gas Industry. In Proceedings of the 14th International Conference on Ground Penetrating Radar (GPR), Shanghai, China, 4-8 June 2012. [CrossRef]

94. Persico, R. Introduction to Ground Penetrating Radar: Inverse Scattering and Data Processing; Wiley-IEEE: Hoboken, NJ, USA, 2014; ISBN 978-1-118-30500-3.

95. Ludeno, G.; Capozzoli, L.; Rizzo, E.; Soldovieri, F.; Catapano, I.A. Microwave Tomography Strategy for Underwater Imaging via Ground Penetrating Radar. Remote Sens. 2018, 10, 1410. [CrossRef]

96. Oskooi, B.; Parnow, S.; Smirnov, M.; Varfinezhad, R.; Yari, M. Attenuation of random noise in GPR data by image processing. Arab. J. Geosci. 2018, 11, 677. [CrossRef]

97. Slemmons, D.B. Geological effects of the Dixie Valley-Fairview Peak, Nevada, earthquakes of December 16, 1954. Bull. Seismol. Soc. Am. 1957, 47, 353-375.

98. Caskey, S.J.; Wesnousky, S.G. Static stress changes and earthquake triggering during the 1954 Fairview Peak and Dixie Valley earthquakes, central Nevada. Bull. Seismol. Soc. Am. 1997, 87, 521-527.

99. Zuo, J.; Wu, Z.H.; Ha, G.; Hu, M.; Zhou, C.; Gai, H. Spatial variation of nearly NS-trending normal faulting in the southern Yadong-Gulu rift, Tibet: New constraints from the Chongba Yumtso fault, Duoqing Co graben. J. Struct. Geol. 2021, 144, 104256. [CrossRef]

100. Pantosti, D.; Schwartz, D.P.; Valensise, G. Paleoseismology along the 1980 surface rupture of the Irpinia fault: Implications for earthquake recurrence in the Southern Apennines, Italy. J. Geophys. Res. 1993, 98, 6561-6577. [CrossRef] 